\title{
The effect of blood transfusion to the recipient and drug pretreatment of the donor on canine allograft survival
}

Citation for published version (APA):

van der Linden, C-J. (1981). The effect of blood transfusion to the recipient and drug pretreatment of the donor on canine allograft survival. [Doctoral Thesis, Maastricht University]. Rijksuniversiteit Limburg. https://doi.org/10.26481/dis.19811113cl

Document status and date:

Published: 01/01/1981

DOI:

10.26481/dis.19811113cl

Document Version:

Publisher's PDF, also known as Version of record

\section{Please check the document version of this publication:}

- A submitted manuscript is the version of the article upon submission and before peer-review. There can be important differences between the submitted version and the official published version of record.

People interested in the research are advised to contact the author for the final version of the publication, or visit the DOI to the publisher's website.

- The final author version and the galley proof are versions of the publication after peer review.

- The final published version features the final layout of the paper including the volume, issue and page numbers.

Link to publication

\footnotetext{
General rights rights.

- You may freely distribute the URL identifying the publication in the public portal. please follow below link for the End User Agreement:

www.umlib.nl/taverne-license

Take down policy

If you believe that this document breaches copyright please contact us at:

repository@maastrichtuniversity.nl

providing details and we will investigate your claim.
}

Copyright and moral rights for the publications made accessible in the public portal are retained by the authors and/or other copyright owners and it is a condition of accessing publications that users recognise and abide by the legal requirements associated with these

- Users may download and print one copy of any publication from the public portal for the purpose of private study or research.

- You may not further distribute the material or use it for any profit-making activity or commercial gain

If the publication is distributed under the terms of Article $25 \mathrm{fa}$ of the Dutch Copyright Act, indicated by the "Taverne" license above, 
The effect of blood transfusion to the recipient and drug pretreatment of the donor on canine allograft survival 
Zetwerk, layout en opmaak: Pecasse-Eurozet b.v., Maastricht Druk en afwerking: Offset Kurver b.v., Sittard 


\section{The effect of blood transfusion to the recipient and drug pretreatment of the donor on canine allograft survival}

\section{PROEFSCHRIFT}

Ter verkrijging van de graad van doctor in de geneeskunde aan de Rijksuniversiteit Limburg te Maastricht, op gezag van de rector magnificus Prof. Dr. W.H.F.W. Wijnen, volgens besluit van het College van Dekanen in het openbaar te verdedigen in de aula van de universiteit op vrijdag 13 november 1981 des namiddags te vier uur

door

Cornelis-Jan van der Linden

geboren te 's-Gravenhage. 
Promotoren : Prof. Dr. J. Jeekel Prof. Dr. J.M. Greep

Referenten : Prof. Dr. D.W. van Bekkum

Prof. Dr. K.H. Rahn

Prof. Dr. J.J. van Rood 
aan mijn vader 


\section{Contents}

Preface

Chapter I

General introduction

1.1 Graft rejection 11

1.2 Graft rejection and immunosuppression 12

1.3 Graft rejection and tissue typing 13

1.4 Graft rejection and blood transfusion 14

1.5 Graft rejection and donor drug pretreatment 18

Chapter II Introduction to and discussion of the experimental work

2.1 Blood transfusions to the recipient 21

2.2 Pretransplant treatment of the donor

2.3 The combination of blood transfusions to the recipient and pretransplant treatment of the donor $\quad 25$

2.4 Concise outline of the experiments. 25

Summary

Samenvatting

References for chapter I and II

Publications presented in this thesis:

Publication I The effect of blood transfusions on canine renal allograft survival.

Publication II Preoperative immunosuppression with antithymocyte serum and procarbazine: Effect on kidney graft survival in dogs after donor or third-party antigen administration.

Publication III Prolongation of canine renal allograft survival. A study on the effect of donor pretreatment. 
Publication IV A study on the mechanism of donor pretreatment. Effect of procarbazine hydrochloride and methylprednisolone on immunocompetent cells.

Publication $\mathrm{V}$ The effect of transfusions and donor pretreatment on canine renal allograft survival.

Acknowledgements

Curriculum vitae 


\section{Preface}

Today renal transplantation is a well defined controlled procedure. Approximately 50,000 kidney transplantations have been performed in man and at present kidney loss due to technical errors and complications accounts for only 1-4 percent of graft failures (Helling 1980, Rapaport, 1981).

At this moment kidney graft rejection is the most frequent cause of kidney graft failure. Long lasting graft function can only be envisaged in man after continuous suppression of the recipient's immune system with immunosuppressive agents after transplantation. Despite such an immunosuppressive treatment $30-40 \%$ of all renal grafts are lost due to rejection in the first year of transplantation (13th report of Human renal transplant registry, 1977). Moreover, immunosuppressive agents administered to the recipient cause non-specific immunosuppression which also affects host resistance against bacterial, viral, protozoal and fungal infections and permits a 2 to 4 times increased annual death rate due to malignant diseases in transplanted patients (Mc Henry 1976, Jacobs 1981). The incidence of septicemia varies from 20 to $35 \%$ of the patient population and a mortality of 35 to $75 \%$ in this group has been reported (Murphy 1976, Lee 1977, Chatterjee 1979). Although it has been claimed that the incidence of infection has decreased drastically within the last few years (Alexander 1980), a recent report of 942 allograft patients shows that $38 \%$ of mortality is still caused by infection (McDonald 1981). Furthermore, immunosuppressive agents e.g. glucocorticoids, antimetabolites and cytotoxic agents, all have a long list of major and minor drug specific side effects (Prompt 1977, Chatterjee 1979).

To decrease patient morbidity and mortality all possible efforts have to be made to improve graft survival by methods other than non-specific immunosuppressive drug therapy.

In this thesis treatment of the donor before procuring the kidney as well as manipulation of the host before transplantation are considered. Since drug pretreatment of the donor and transfusions of the recipient may alter alloimmune responsiveness and thereby prolong graft survival without strong non-specific immunosuppression, it was thought worthwhile to investigate both. When the experiments underlying this study were started, it was generally accepted that blood transfusions given to the recipient before transplantation would improve overall graft survival in man. Experimental data confirmed the beneficial effect of blood transfusions, (Van Es 1977, Bull 1978), but controversial opinions existed on the underlying mecha- 
nism(s) leading to improved graft survival. Furthermore it was considered that blood transfusions might sensitize a transplantation candidate, and sensitized patients are considered unfit for transplantation. For this reason a deliberate transfusion scheme for all transplantation candidates was thought to bear too many risks. Many questions had to be answered. No concensus existed on the relation between the number of blood transfusions and graft survival, the desirable type of transfusion and the optimal time interval between transfusion and transplantation.

The effect of treatment of the graft in situ in the donor is still a subject of debate. Although a beneficial effect of donor drug pretreatment had already been reported in 1973 (Guttmann 1973), others could not confirm this observation (Jeffery 1978, Soulillou 1979). Several hypotheses had been proposed for the mechanisms which mediate prolongation of graft survival, but none could satisfactorily explain the reported differences in graft survival obtained by donor drug pretreatment.

In this thesis the effect of blood transfusions and donor pretreatment have been studied alone and in combination. Their effects on renal graft survival have been tested in dogs. Transplantation studies in the dog lead to results comparable with those obtained in man. In vitro and in vivo studies have been performed in an attempt to elucidate some of the underlying mechanisms. Knowledge of these mechanisms may establish a basis for more sophisticated combined pretreatment schedules. 


\section{General introduction: renal allograft transplantation in man}

In 1936, Voronoy, a Russian surgeon, performed the first renal allograft transplantation in man. A 26 year old woman with an anuria caused by bichloride of mercury poisoning received a cadaver donor kidney from a patient who had died from encephalitis. The kidney was transplanted into the groin of the patient. Some urine production was observed initially, but the patient died the second day of transplantation after the urine production became bloody and had finally ceased (Voronoy 1936).

Previously renal xenografts (table 1) have been transplanted into man after technical aspects concerning the problem of vascular anastomosis had been solved (Carrel 1902).

Table 1. Landmarks in human renal transplantation surgery.

\begin{tabular}{|c|c|c|}
\hline 1902 & Ullmann & $\begin{array}{l}\text { First attempt to transplant a renal xenograft in } \\
\text { the circulatory system of a patient. }\end{array}$ \\
\hline 1910 & Clinger & $\begin{array}{l}\text { First intracorporal location of a renal xenograft } \\
\text { in a patient. }\end{array}$ \\
\hline 1936 & Voronoy & First transplantation of a human renal allograft. \\
\hline 1950 & Lawler & $\begin{array}{l}\text { First intraabdominal location of a renal human } \\
\text { allograft. }\end{array}$ \\
\hline 1951 & Küss & First living human donor transplantation. \\
\hline 1953 & Michon & First living related human donor transplantation. \\
\hline 1954 & Murray & $\begin{array}{l}\text { First living related human donor transplantation } \\
\text { between monozygotic twins. }\end{array}$ \\
\hline
\end{tabular}

\subsection{Graft rejection}

Williamson in 1923 concluded from renal transplantation studies in the dog that failure of kidney transplants was attributable to a biologic incompatibility between donor and recipient (Williamson 1923).

In 1944 Medawar in his classical studies with rodent skin grafts established the immunological basis of rejection (Medawar 1944). In 1955 Hume et al. summarized the results in experimental animals and man and concluded from these data and his own experiences with the transplantation of nine human cadaver kidneys that 'renal homotransplantation has no place in the therapy of human patients at this time' (Hume 1955). This conclusion was based on the observation that despite good surgical performances and 
meticulous posttransplantation care nearly all patients died within a few days with the exception of a few who survived a couple of months. Although some patients received ACTH or cortisone postoperatively, adequate immunosuppression was not applied until 1958 when graft rejection was favourably influenced by total body irradiation (Murray 1960).

\subsection{Graft rejection and immunosuppression}

By the early 1960's 32 patients had been reported in whom total body irradiation was the sole immunosuppressive measure of which only 4 survived for more than one year. Reasons for failure included serious side effects of irradiation and rejection of the graft (Groth 1972). The great risk and highly unpredictable effect of total body irradiation made the undertaking impractical (Starzl 1978).

The future of transplantation in man was changed by the discovery that steroids (Billingham 1951) and thiopurine compounds (Calne 1960, Schwarz 1960) had an immunosuppressive effect. Pharmacological immunosuppression using glucocorticoids and antimetabolites in man dates from 1963 when Starzl et al. reported excellent results in eight transplantations in which the donors were living relatives and the recipients were treated with the combination of azathioprine and prednisone (Starzl 1963). These immunosuppressive drugs can be continuously adjusted and are less dangerous than total body irradiation. They made kidney transplantation an applicable treatment for endstage renal failure patients. Corticosteroids and azathioprine are still the most important immunosuppressive agents for the prevention and treatment of graft rejection today. Both agents, however, have an impressive list of side effects affecting practically any organ of the body.

Many other agents have been investigated but none has been demonstrated to parallel the safety and efficacy of these two drugs. Anti-lymphocyte serum is already fifteen years in use, and although several centers using anti-lymphocyte globulin in their postoperative management to prevent graft rejection have extremely good graft survival percentages, one is still awaiting standardisation of production (Monaco 1977, Cosimi 1981, Groth 1981). Prospective clinical studies are in progress to investigate its value in human renal transplantation. With the introduction of cyclosporin $A$, a completely new type of immunosuppressive agent has been added to the armory of immunosuppressive agents (Borel 1976). Results in several species were exciting, which prompted Calne and others to perform preliminary studies in man (Calne 1978). At this moment cyclosporin A has shown its effectiveness to prolong graft survival in an increasing number of patients who received renal allografts. Cyclosporin $A$ has a partially specific immunosuppressive effect in that it acts at an early stage in T cell differentiation or possibly on a subpopulation of these lymphocytes (Gordon 1979, White 1979). The drug is devoid of myelotoxicity, which is in contrast with other immunosuppres- 
sants such as anti-lymphocyte globulin and azathioprine. Since cyclosporin A can be used as the sole immunosuppressive agent the troublesome side effects of glucocorticoids and azathioprine can often be avoided. However, a considerable number of relatively harmless and more serious side effects have thus far been noticed, and a possibly increased incidence of lymphosarcoma has been reported, which might be caused by the lack of production of cytotoxic T cells (Calne 1980, Crawford 1981). At this moment it has to be concluded that cyclosporin A will possibly decrease patient morbidity and mortality but an effective and totally safe immunosuppression remains an elusive objective.

Other immunosuppressive procedures include thoracic duct drainage and total lymphoid irradiation.

Thoracic duct drainage, a difficult technical procedure, has been performed in several centers and seems to influence graft survival positively. A high incidence of lethal septic complications after thoracic duct drainage has been reported however, and technical problems will hinder wide use of this procedure (Traeger 1978, Starzl 1979, Fisch 1981). Finally total lymphoid irradiation of the recipient has recently been advocated as an effective method to provide better graft survival (Slavin 1977). This technique has been designed to permit high radiation doses to all of the major lymphoid structures of the body, while shielding adjacent vital organs and tissues. Total lymphoid irradiation has become a standard programme for the treatment of Hodgkin's disease and non-Hodgkin lymphoma.

Sufficient experience with transplantation patients is still lacking to evaluate its worth in clinical practice at this moment (Slavin 1980, Najarian 1981).

\subsection{Graft rejection and tissue typing}

Graft rejection occurs if the immune system of the recipient recognizes donor antigens in the transplanted organ as 'non-self'. Cells belonging to the donor immune system in the transplanted organ (= passenger leukocytes) which recognize the recipient antigens as 'non-self' may be another factor contributing to graft rejection (Elkin 1968, Van Schilfgaarde 1978).

A variety of antigens is present on the cells of each individual. The genetic codes for all antigens reside in genes on different chromosomes. One particular chromosomal region, on the six th chromosome, the Major Histo-Compatibility Region encodes for the strongest histocompatibility antigens (HLA-A, $\mathrm{B}, \mathrm{C}$, and $\mathrm{D} / \mathrm{DR}$ in man). This region has been identified in many species. Identification of antigens coded by this region is possible and matching of donor and recipient for these antigens is nowadays widely used. This procedure reduces graft rejection and thereby increases kidney graft survival (Van Rood 1967, Van Rood 1977, Albrechtsen 1979, Ting 1980). But apart from these 'major' histocompatibility antigens and the vitally important blood group antigens $\mathrm{ABO}$, other allo-antigens exist and they are most likely the 
explanation that fatal graft rejection even in a HLA identical donor-recipient combination will occur if adequate immunosuppression is omitted (Paul 1979, Oriol 1980, Vegt 1981).

The role of the different types of antigens is not the subject of investigation of this thesis and will therefore not be discussed.

\subsection{Graft rejection and blood transfusions}

In 1967 Dossetor et al. analysed 29 patients with renal allografts. Among other factors, the effect of blood transfusions given before transplantation was statistically examined. They reported a significant higher number of blood transfusions in patients whose grafts survived longer. This was the first publication stating a beneficial effect of blood transfusion on renal allograft survival (Dossetor 1967). In 1973 Opelz et al. confirmed this effect for both buffy coat poor and for whole blood transfusions in a retrospective multiple center study including 148 patients (Opelz 1973).

Since 1973 multiple publications about the relation between preoperative blood transfusions and graft survival have appeared. For a summary of the most important studies until 1979 one is referred to a review by Van Es and Balner (1979). The beneficial effect of preoperative blood transfusions has now been accepted by almost all clinicians working in the field of transplantation. The overall outcome of renal cadaver transplantation in man seems to a greater degree to be influenced by the effect of pretransplant blood transfusions than by any other variable (Spees 1980). Many questions remain unanswered. No consensus exists on some essentials which are studied in this thesis: The relation of the number of blood transfusions and their effect on graft survival and the desirable type of transfusion. The optimal time interval between transfusion(s) and transplantation, has still not been established and many controversial opinions exist on the underlying mechanisms leading to decreased graft rejection.

The effect of blood transfusions on kidney graft survival is the main subject of some of the experiments of this thesis. Therefore a more detailed discussion of some aspects of blood transfusion and kidney graft survival in man is surveyed.

\subsubsection{The relation between number of blood transfusion and renal allograft survival}

The question whether or not an increasing number of transfusions will improve graft survival percentages remains controversial. Opelz and Terasaki reviewing the graft survival of 2,580 recipients obtained from 68 transplant centers in the United States and Canada retrospectively found a clearly positive effect of increasing numbers of transfusions on graft survival (Opelz 1980). A significant difference in graft survival was calculated between patient groups receiving zero transfusions and those receiving $1-5$ units 
of blood as well as between patient groups receiving 1-5 transfusions and those receiving more than 5 units of blood. A significantly higher cumulative renal graft survival in polytransfused patients has also been reported by others (Schmidt 1978, Fehrman 1980), and was recently again confirmed by the forementioned authors in a non-randomised prospective study (Opelz 1981).

Contrary, some authors reported that more than 5 transfusions do not add to the beneficial effect (Husberg 1977, Salvatierra 1981). No significant increase in graft survival could be detected by Opelz and Terasaki after one single preoperative blood transfusion of whole blood ( 30 patients) or of frozen blood (33 patients). Surprisingly one transfusion of packed cells (123 patients) did increase one year graft survival $(59 \pm 5 \%)$ compared to no transfusions $(41 \pm 2 \%)$, however the improvement was only half the one obtained by more than 20 transfusions ( $75 \pm 5 \%$ ) (Opelz 1980). Persijn et al. (1979) in a retrospective and prospective study of respectively 30 and 19 patients obtained from 6 Dutch transplantation centers reported a substantial increase in one year graft survival after only one preoperative transfusion of whole blood or leukocyte poor blood. The one year graft survival was $32 \%$ in the control group which never received a blood transfusion versus $87 \%$ in the retrospective group and $79 \%$ in the prospective group which both received only one transfusion. Persijn attributes the difference in the observed effect of one preoperative blood transfusion in his and Opelz's study to the fact that Opelz's study encompasses racially heterogeneous patients from many different centers. Racial differences in the distribution of minor histocompatibility antigens may possibly account for this effect (Jonassen 1.981).

\subsubsection{Type of preoperative blood transfusion and renal allograft survival in man}

Patients may be transfused with several types of blood preparations. The most widely used transfusions are packed cells, whole blood and leucocytepoor blood and less frequently frozen red blood cells and leukocyte-free blood.

The beneficial effect of packed cells, whole blood as well as leukocyte. poor blood has been observed by most investigators. Frozen blood has been found to be effective by some authors (Fuller 1977, Perkins 1977, Polesky 1977, Briggs 1978) although Opelz et al. reported no effect of frozen blood in a study of 215 patients (Opelz 1974, 1978, 1980). The latter authors concluded that the trend to convert blood transfusions to frozen blood transfusions may be a move in the wrong direction for transplantation candidates. Leukocyte-free blood, 1 to 3 units, did not improve the 1-year graft survival in 8 patients (Persijn 1979).

It remains to be solved which type of transfusion will be the ideal transfusate for deliberate transfusion schemes. 


\subsubsection{The influence of the time interval between blood transfusion and}

transplantation on renal allograft survival

Blood transfusions seem to have a beneficial effect on graft survival even if the transfusion has been given years before transplantation. However, the effect is probably more prominent for transfusions given within one year before transplantation than those given two or more years before transplantation (Buy-Quang 1977, Hourmont 1979). Transfusions given within half a year before transplantation enhance graft survival independently of the length of the period between transfusion and transplantation (Persijn 1979, Corry 1980).

The effect of a peroperative transfusion is a matter of great debate. Until now it was generally considered that peroperative transfused blood did not alter graft survival. Recently several studies have been published which suggest a beneficial effect of peroperative given transfusions. Table 2 summarizes the results obtained with peroperative blood transfusions on kidney graft survival.

\subsubsection{Mechanisms leading to improved renal allograft survival after blood transfusion(s)}

The mode of action of the immunosuppressive effect of blood transfusions has been subject to speculation. Nearly all known immunological phenomena have been suggested. One of the most suggested possibilities is that 'immunological tolerance' is induced by transfusions. Enhancing or antiidiotypic antibodies are other suggested mechanisms (Opelz 1979). A third possibility is that host's suppressor cells are formed after transfusion (Van Rood 1979). A selection of socalled responders and non-responders have been suggested as a fourth possibility (Opelz 1972). And lastly non-specific immunosuppressive mechanisms as macrophage blockade have been proposed (Keown 1979). Since graft survival extension can be obtained by a wide variation of different immunisation schedules with the use of several blood products it is likely that a chain of subtle immunological events (specific and non specific) determines the final outcome of blood transfusions on renal allograft survival (Van Es 1981).

Very recently we studied the effect of blood transfusions given to the donor. A significant better one year graft survival was found if the kidney had been harvested from a transfused donor (Jeekel 1980). If confirmed, this new observation necessitates a re-evaluation of possible mechanisms.

\subsubsection{Blood transfusion and donor-recipient matching}

The beneficial effect of blood transfusions has been found for all cadaver kidney donor-recipient combinations, matched and fully mismatched (Persijn 1979, Opelz 1980). The effect of previous blood transfusions on renal allograft survival in living related transplantation is controversial. Signifi- 


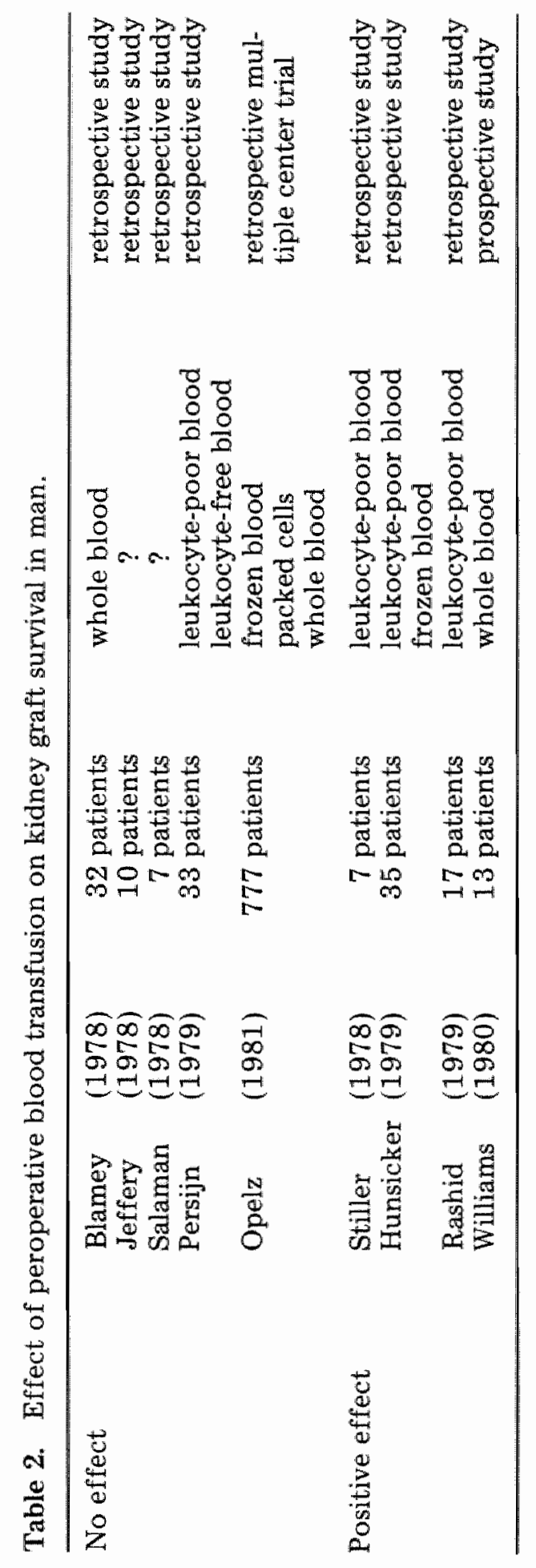


cantly improved results after blood transfusions in this combination have been obtained for one haplotype mismatched combinations (Brynger 1977, Solheim 1980). On the other hand no effect of blood transfusions on graft survival has been reported for living related transplantations (Oei 1979). Recently excellent graft survival has been observed after donor specific blood transfusions given preoperatively in living related donor-recipient combinations if the recipient did not show sensitization to the donor preoperatively (Cochrum 1981).

Lastly one transplantation center reported a significant improvement in graft survival after blood transfusions in recipients with blood group $\mathrm{O}$ in contrast to recipients with blood group A, B and AB (Joysey 1977).

Sofar no data are available on the effect of matching for blood transfusions and prospective recipients on renal allograft survival.

\subsection{Graft rejection and donor drug pretreatment}

Pretreatment of the donor is an attractive approach to influence graft survival for it might improve results of kidney graft survival without burdening of the recipient. A combined work-up schedule including blood transfusions, donor-recipient matching and donor pretreatment is practically feasible.

In 1973 Guttmann et al. were the first to describe a decrease in the number of graft rejections in man after pretreatment of the donor before nephrectomy (Guttmann 1973). A combination of $5 \mathrm{~g}$. methylprednisolone and $3 \mathrm{~g}$. cyclophosphamide had been administered to the donor some hours before nephrectomy. Studies reporting an improved kidney graft survival after donor drug pretreatment using methylprednisolone and cyclophosphamide in man followed (Beaudoin 1973, Guttmann 1975, Zincke 1977, Guttmann 1978, Zincke 1978, Corry 1980, Guttmann 1980). These studies did not definitely prove its beneficial effect, since most of them compared the survival of donor drug pretreated kidney grafts with historical controls and all dealt with a small number of patients.

Prospective studies on the effectiveness of donor drug pretreatment on renal allograft survival could not establish its effectiveness with the exception of the study of Corry et al. (Chatterjee 1977, Barry 1978, Jeffery 1978, Soulillou 1979, Corry 1980). Table 3 reviews the data of donor drug pretreatment in renal allograft transplantation.

A truly randomised large multicenter clinical trial still needs to be executed to establish the value of donor drug pretreatment. It has to be stressed that if donor drug pretreatment is effective in improving graft survival in cadaver donor transplantations even a small improvement in one year graft survival would be worthwhile. Fewer graft rejection episodes due to donor drug pretreatment would allow a decrease of non-specific immunosuppressive agents. The risk of infections in these highly susceptable 


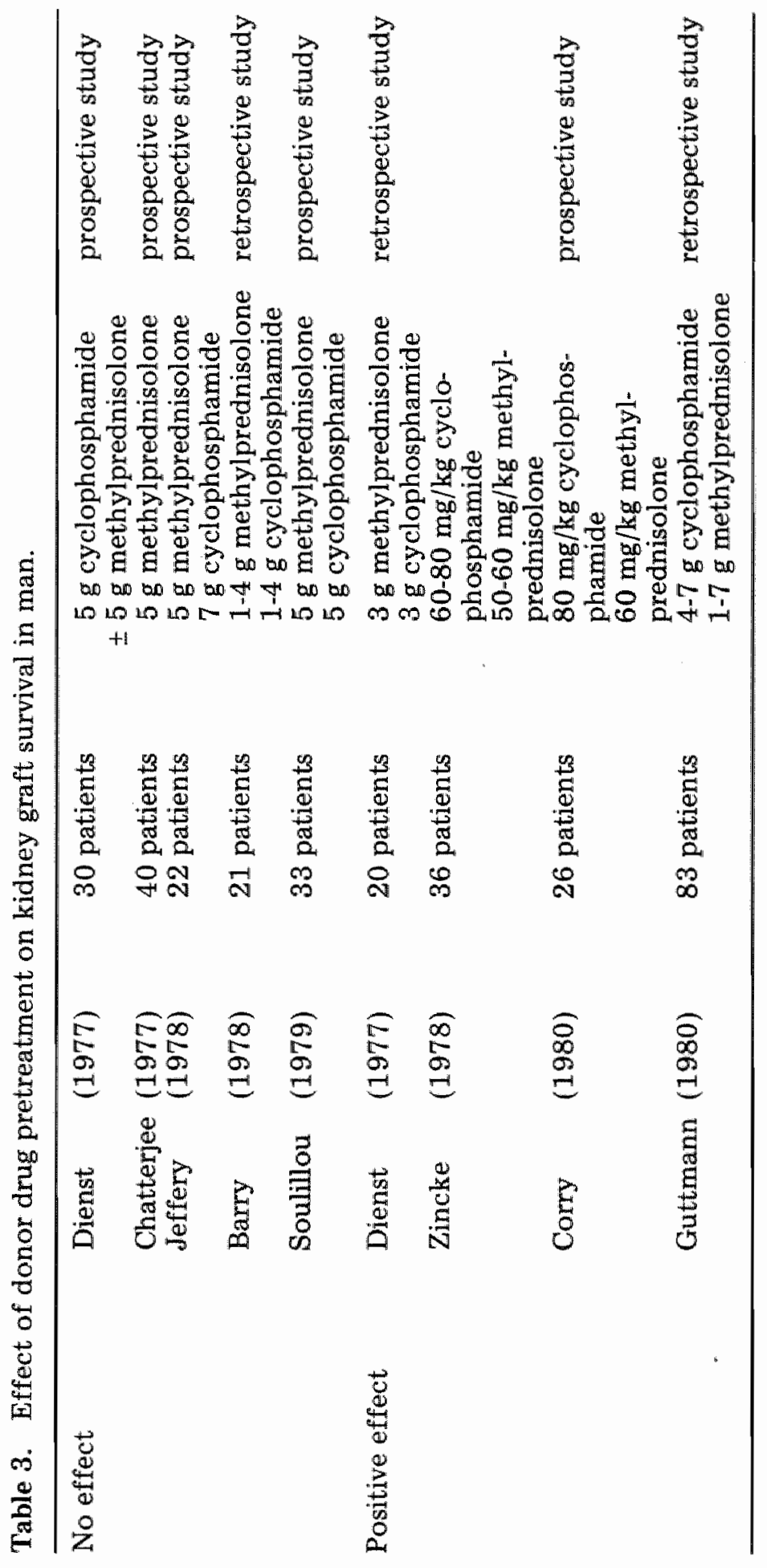


patients would diminish and the incidence of drug specific side effects would decrease.

Furthermore it has to be established whether or not a possible beneficial effect of donor drug pretreatment is additive to other known favourable factors, not harmful to the recipient. The simultaneous effect of blood transfusions and donor drug pretreatment is of utmost interest, since both treatments are easily to combine.

\subsubsection{Mechanisms leading to improved renal allograft survival after donor pretreatment}

Several hypotheses for the mechanisms, which mediate prolongation of graft survival have been made. Three possibilities have been considered to be the most likely explanations for prolonged kidney graft survival induced by donor drug pretreatment. Firstly it was considered that donor drug pretreatment might lower the number of passenger leukocytes and secondly it was considered that donor drug pretreatment might lower the antigenicity of the graft. The third possibility is the presence of drug metabolites within the transplanted graft leading to local immunosuppression of the recipient. The mechanism of donor pretreatment is subject of study in experiments of this thesis, here it suffices to state that none of the hypotheses have been excluded thus far.

\subsubsection{The combination of pretransplant blood transfusion and donor drug} pretreatment. Their combined effect on renal allograft survival

Little information exists on the effect of the combination of pretransplant blood transfusion and donor drug pretreatment on renal allograft survival in man. No significant difference in graft survival could be found in the transfused or non-transfused patients in the 93 pretreated kidneys of Guttmann et al. (1980) (42 patients non-transfused, 34 patients 1-5 transfusions, 17 patients $>5$ transfusions), and in the 26 pretreated grafts of Corry (1980) (8 patients received transfusions). Both authors reported a beneficial effect of donor drug pretreatment.

Soulillou et al., who found no effect of donor drug pretreatment on kidney graft survival, could not establish a significant difference in graft survival of pretreated kidneys after blood transfusions. (22 patients received a pretreated kidney and had been transfused, 11 patients received a pretreated kidney and had never been transfused) (Soulillou 1979).

Further information is lacking and since many differences existed between the forementioned groups, which included only a small number of patients, no conclusion can be drawn from these data. 


\section{Introduction to and discussion of the experimental work}

Experiments have been designed in order to improve kidney graft survival without burdening the immune system of the recipient. In this thesis blood transfusions to the recipient and donor pretreatment are subject of investigation.

As outlined in the general introduction the overall beneficial effect of blood transfusions in man is nowadays generally accepted but the ideal type of deliberate transfusions has not yet been determined. The effect of drug pretreatment of the donor on kidney graft survival in man is highly questionable since conflicting data of the effect of treatment on kidney graft survival have been obtained.

The effect of transfusions with different types of blood products, given during or shortly before transplantation, on canine renal allograft survival has been studied in this thesis. Furthermore the effect of donor drug pretreatment on canine renal allograft survival has been investigated and experiments have been performed to reveal the mechanism leading to improved graft survival after donor drug pretreatment.

In clinical practice a complex treatment schedule is often used. The possibility that combinations of treatments do not improve or may even impair results obtained by either one treatment has to be considered. Therefore combined treatment experiments have also been performed in this study.

\subsection{Blood transfusions to the recipient}

In 1977, based on poor kidney graft survival obtained in non-transfused patients ( $32 \%$ graft survival after 1 year), Eurotransplant Leyden, decided to transfuse their patients with one unit of leukocyte-poor blood or with one to three units of leukocy te-free blood preoperatively.

In this prospective study a one year graft survival of $79 \%$ was observed in the patient population which received one unit of leukocyte-poor blood. Surprisingly however $75 \%$ of the patients which received one to three units of leukocyte-free blood rejected the kidney graft within 1-year (Persijn 1979). These data suggest that leukocytes within the tranfused blood may be essential to obtain improved graft survival by blood transfusions.

Up until recently the effect of peroperative blood transfusions on kidney 
graft survival was thought to be negligible. However, in 1980 Williams et al. published a prospective study claiming a beneficial effect of 2 units of whole blood given during the operation ( $85 \%$ compared to $34 \%$ of the control group) (Williams 1980). Therefore it remains to be established whether or not one blood transfusion administered peroperatively will improve graft survival.

In the first publication of this thesis, the effect of one transfusion with several blood products given before or during kidney transplantation has been examined. The experiments were performed with kidney grafts in dogs. For monkeys Van Es et al. showed that transfusions of whole blood given during or shortly before transplantation could prolong kidney graft survival. In this group of monkeys he did not find any accelerated graft rejection (Van Es 1978). A beneficial effect of several preoperative blood transfusions on canine allograft survival had been observed earlier (Abouna 1977, Obertop 1978). Sensitization of the recipient after multiple transfusions in the dog has also been documented (Bull 1978, Fabre 1978). These observations indicate that the dog transplantation model is an appropriate model to perform experimental studies on the effect of blood transfusions on renal allograft survival.

The main aim of the study in this chapter was to investigate the effect of different types of blood transfusions given peroperatively on kidney graft survival. Sensitization caused by preoperative transfusions is the most serious drawback of deliberate transfusions to transplantation candidates in man. A beneficial effect of peroperative blood transfusions which of course do not sensitize recipients preoperatively would therefore have important clinical implications, but this effect has first to be investigated in experimental models.

We have demonstrated a prolonged kidney graft survival in a canine model by a whole blood transfusion of the recipient during operation. It was further demonstrated that peroperative transfusions with leukocyte-free blood, with lymphocyte suspensions and with irradiated whole blood were ineffective in prolonging kidney graft survival.

The fact that prolonged graft survival after a peroperative transfusion was only obtained after a transfusion with fresh whole blood suggests that immunocompetent cells capable to proliferate are important in obtaining kidney graft survival extension after blood transfusions.

A beneficial effect of a single whole blood transfusion given 14 days before transplantation was observed only if the recipient had been immunosuppressed preoperatively with azathioprine and prednisone. This last experiment suggests that immunosuppression during or shortly after transfusion might be essential for the induction of the beneficial effect of blood transfusions in this model.

A non-specific blockade of host macrophages by transfused erythrocytes, a mechanism suggested by Keown and Descamps, is not likely to be the cause of kidney graft survival prolongation in this experimental model (Keown 1979). The forementioned hypothesis was based on observations by 
Keown and Descamps in mixed leukocyte cultures. They reported a reduction in MLC response after macrophage blockade by an erythrocyte lysate, by purified hemoglobin and by $\mathrm{Fe}^{3+}$ ions. The essential role of adherent cells of the mononuclear phagocytic system in the lymphocyte transformation responses to antigens has been established (Mookerjee 1979). A strong depression of mixed lymphocyte reaction after removal of adherent cells from both responder and stimulator populations had been obtained. Such purified lymphocytes were able to respond well when mixed with adherent cells autologous with the responder (Pawelec 1978). However adherent cells seem to exert a dual effect causing either stimulation or inhibition of proliferation (Berlinger 1976, Garriques 1981, Laughter 1981). In man it has been shown that individuals with low proliferative responses to concanavalin A exhibit marked increases in responsiveness when adherent cells are removed (Zighelboim 1981). We found that transient unresponsiveness to canine leukocytes of DLA dissimilar leukocytes could be improved by depletion of phagocytizing cells by carbonyl iron treatment (unpublished data). A regulatory function of mononuclear phagocytes i.e.: stimulation by antigen processing and interleukin 1 production as well as inhibition by prostaglandin production is assumed.

This dual effect makes the in vitro model used by Keown and Descamps for the in vivo effect of blood transfusions on renal allograft survival an untenable model.

In the second publication, the effect of pretransplant immunosuppression of the recipient in combination with the administration of donor or third party blood products to the recipient has been investigated.

In 1974 Storb et al. showed that sensitization by donor blood transfusions could be successfully suppressed by a combination of procarbazine hydrochloride and antithymocyte serum (ATS). Dogs which were immunised by two donor blood transfusions showed an acute marrow graft rejection despite the administration of $1,200 \mathrm{R}$ of total body irradiation. Pretransfused recipients, which received pretransplant immunosuppression with procarbazine hydrochloride and ATS however accepted the marrow graft (Storb 1974). Prolonged to indefinite graft survival has been obtained with this combined pretransplant recipient treatment schedule in mice for skin and heart allografts (Floersheim 1969, 1973, Brent 1979). Harder et al. reported prolonged renal allograft survival in dogs after pretransplant administration of donor antigens plus immunosuppression of the recipient with procarbazine hydrochloride and ATS (Harder 1979). Earlier it was shown that procarbazine hydrochloride alone or in combination with azathioprine did not prolong canine kidney allograft survival (MacDonald 1971, Varkarakis 1972).

The aim of the study of this chapter was to investigate the influence on graft survival of preoperatively given donor antigens to immunosuppressed recipient dogs. This was necessary because earlier studies on the effect of preoperatively given donor antigens on the survival of canine renal allografts were conflicting (Calne 1966, Halasz 1966, Linn 1966, Zimmer- 
man 1968, Wilson 1969). The effect of this combined pretreatment schedule has been furthermore investigated in a one haplotype different donorrecipient model, since the clinical application of this schedule would be most feasible in a living related donor-recipient combination.

Improved kidney graft survival with pretransplant immunosuppression of the recipient with procarbazine hydrochloride and ATS after preoperative transfusions of different types of donor specific antigenic material was observed in unmatched mongrel dogs. Extension of kidney graft survival was not observed in one haplotype different littermate beagles. Therefore this study does not favour the clinical application of this combined pretreatment schedule for living related combinations. Furthermore prolongation of kidney graft survival in this model did not depend on the administration of donor specific antigens, since the administration of third party serum led to graft prolongation of equal extent. This finding indicates that the observed phenomenon is quite comparable with the observations made in the first publication using third party blood transfusions.

\subsection{Pretransplant treatment of the donor}

In the third publication the effect of donor drug pretreatment on renal allograft survival is described in dogs. A combination of procarbazine hydrochloride and methylprednisolone was chosen as drug pretreatment. This combination of drugs led to prolonged kidney graft survival in earlier studies in the dog (Zincke 1974). The experiments confirmed that donor pretreatment with procarbazine hydrochloride and methylprednisolone leads to prolonged kidney graft survival in the dog. The effect of administration of donor blood constituents during transplantation on the prolonged graft survival due to donor pretreatment has been investigated to obtain information on possible mechanisms leading to prolonged graft survival after donor drug pretreatment. A peroperative transfusion of donor blood constituents, whether lymphocytes or leukocyte-poor blood, abrogated the beneficial effect of donor pretreatment on kidney graft survival. The data showed that donor antigens given systemically during transplantation nullify the beneficial effect of donor drug pretreatment. It is discussed that the beneficial effect of donor drug pretreatment on renal allograft survival might be due to a local immunosuppressive effect of small amounts of drugs within the transplanted kidney. This is in accordance with recent data which showed that after an effective donor drug pretreatment schedule with cyclophos. phamide and methylprednisolone ${ }^{14} \mathrm{C}$-labeled metabolites of cyclophospha. mide can be detected in the transplanted kidney (Brom 1980).

The effect of procarbazine hydrochloride and methylprednisolone on peripheral immunocompetent cells in the dog has been tested in further experiments which are described in the fourth publication.

In 1976 Jeffery published data on the effect of cyclophosphamide and methylprednisolone on peripheral leukocytes in MLC in man, in which he 
described decreased MLC response after donor pretreatment (Jeffery 1976).

A decrease in peripheral lymphocyte count 5 hours after the start of donor pretreatment with procarbazine hydrochloride and methylprednisolone was shown, whilst the total number of peripheral white blood cells increased significantly. The percentage of surface immunoglobulin positive cells of the lymphocyte fraction remained unaltered, which indicated that neither $\mathrm{T}$ nor $\mathrm{B}$ cells were depleted specifically. A depression of responsiveness and stimulation capacity of buffy coat leukocytes from pretreated animals was found in MLC, which could be completely reversed by purification by Lymphoprep density centrifugation followed by careful washing of these cells.

This effect could not be attributed to the low amount of serum of pretreated animals present within the cultures of buffy coat leukocytes.

The data suggested that the depression of MLC-responses was most likely due to drug metabolites in or on the cells. It confirmed the earlier stated hypothesis that a small amount of drugs in or on graft cells led to prolongation of renal allograft survival after donor drug pretreatment.

2.3 The combination of blood transfusions to recipient and pretransplant treatment of the donor

Combinations of treatments do not have to improve or may even impair results obtained by one treatment. In the clinical setting different types of treatments are often combined, therefore we tested the effect of both donor drug pretreatment and transfusions to the recipient on canine renal allograft survival. In the fifth publication it was demonstrated that the combination of donor drug pretreatment and a peroperative blood transfusion did not improve graft survival compared to either treatment alone. Furthermore a third party spleen cell transfusion 14 days before transplantation, which caused a slight sensitization, abrogated the effect of donor drug pretreatment completely.

It was concluded that the clinical data obtained by donor drug pretreatment should be re-evaluated. Differences in policy of a deliberate transfusion of pre- and peroperative blood to transplantation candidates between various centers may account for the obtained conflicting data on the effect of donor drug pretreatment.

\subsection{Concise outline of the experiments}

Peroperative transfusions of third party whole blood prolong kidney graft survival. Third party blood constituents as leukocyte-free blood, lymphocytes and irradiated blood do not extend kidney graft survival. Prolongation of graft survival was found to be dependent on immunosuppression after transfusion, since a preoperative transfusion of third party whole 
Table 1. The transplantation experiments and their results..

\begin{tabular}{|c|c|c|c|c|c|c|c|}
\hline \multirow{3}{*}{$\begin{array}{l}\text { Publi- } \\
\text { cation }\end{array}$} & \multirow{3}{*}{$\begin{array}{l}\text { Donor } \\
\text { Drug } \\
\text { pre- } \\
\text { treat- } \\
\text { ment }\end{array}$} & \multicolumn{4}{|c|}{ Recipient } & & \multirow{3}{*}{$\begin{array}{l}\text { Graft survival } \\
\text { (comparing experimental } \\
\text { transfused group and the } \\
\text { relevant control group) }\end{array}$} \\
\hline & & \multicolumn{2}{|c|}{ Transfusion } & \multicolumn{2}{|c|}{$\begin{array}{l}\text { Immunosup- } \\
\text { pression }\end{array}$} & & \\
\hline & & Donor & $3^{\circ}$ party & Pre-op. & Post-op. & & \\
\hline 1 & & & per-op. & & + & & $\begin{array}{l}\text { whole blood: prolonged } \\
\text { blood constituens; unaltered } \\
\text { irradiated blood unaltered }\end{array}$ \\
\hline & & & $\begin{array}{l}\text { pre-op. } \\
\text { pre-op. }\end{array}$ & + & + & $\overline{-}$ & $\begin{array}{l}\text { whole blood: unaltered } \\
\text { whole blood: prolonged }\end{array}$ \\
\hline 2 & & pre-op. & pre-op. & $\begin{array}{l}+ \\
+\end{array}$ & & - & $\begin{array}{l}\text { prolonged } \\
\text { one haplotype identicall: un- } \\
\text { altered } \\
\text { mismatched: prolonged }\end{array}$ \\
\hline 3 & + & per-op. & & & + & $\overline{-}$ & $\left.\begin{array}{l}\text { prolonged } \\
\text { whole blood } \\
\text { blood constituens }\end{array}\right\} \begin{array}{l}\text { abro- } \\
\text { gation }\end{array}$ \\
\hline 5 & + & & per-op. & & + & - & $\begin{array}{l}\text { prolonged: } \\
\text { comparable to graft survival } \\
\text { after either transfusion or } \\
\text { drug pretreatment }\end{array}$ \\
\hline
\end{tabular}

blood effectively prolonged graft survival only if followed by immediate immunosuppression.

Preoperative transfusions with donor blood, donor plasma or donor liverextract combined with preoperative immunosuppression with ATS and procarbazine hydrochloride also prolong kidney graft survival. However, no extension in graft survival was obtained in one haplotype mismatched donor-recipient combinations. Prolongation of graft survival with preoperative transfusions and preoperative immunosuppression is not dependent on donor specific transfusions, since third party transfusions also enhance graft survival in this model.

Treatment of the donor with high doses procarbazine hydrochloride and methylprednisolone extends graft survival. The administration of donor blood material peroperatively abrogated this prolongation. The combination of a third party blood transfusion with donor pretreatment resulted in a graft survival similar to that of either treatment.

The mechanism leading to enhanced kidney graft survival after donor pretreatment (studied in paper 3 and 4) is most likely caused by small amounts of procarbazine hydrochloride and methylprednisolone or their derivates located in or on graft cells. 


\section{Summary}

Kidney graft rejection is the most frequent cause of kidney graft failure. $30-40 \%$ of all renal grafts are lost due to rejection the first year after transplantation. Furthermore immunosuppressive agents, which are necessary in the prevention and treatment of graft rejection, affect host resistance against infections and increase the risk to develop malignancies. Therefore methods have to be developed which depress graft rejection adequately without the use of high doses of non-specific immunosuppressive agents.

The first chapter of this thesis gives a short historical review describing mile stones in the field of transplantation surgery and immunology. Literature data on the effect of blood transfusions and donor drug pretreatment on kidney graft survival, the two modalities studied in this thesis, are described and discussed. In summary it can be concluded that it is now generally accepted that preoperatively given blood transfusions improve one year graft survival of kidney transplantation. Preoperative blood transfusions can however sensitize the recipient. Sensitization caused by transfusions is the most serious drawback of deliberate blood transfusions to transplantation candidates in man. Preoperative sensitization will not occur with peroperatively given transfusions.

Studies on the effect of peroperatively transfused blood on kidney graft survival in man are not conclusive thus far. In this thesis peroperative blood transfusions were studied in dogs. As described in the first paper, $100 \mathrm{ml}$ third-party whole blood given during transplantation retards fatal graft rejection significantly. A transfusion with leukocyte-free blood, lymphocytes or with irradiated whole blood does not prolong kidney graft survival in this model. These experiments on peroperative blood transfusion show that only fresh whole blood has the capacity to induce graft prolongation. This finding suggests that a peroperative blood transfusion might have a beneficial effect on graft rejection in human renal transplantation. A transfusion with whole blood would be the ideal type of blood for such a peroperative transfusion. A transfusion of whole blood fourteen days before transplantation led to marked prolongation of kidney graft survival if immunosuppression was started directly after transfusion. Suppression of the immune system of the recipient with azathioprine and prednisone therefore enhanced the benefit of blood transfusions on kidney graft survival. Patients with chronic renal failure who are on dialysis do have a suppressed immune system. This immunosuppressed status might be essential for the mechanisms which facilitate the observed improved graft survival after blood transfusions in man. 
In the second publication, prolonged kidney graft survival has been obtained by preoperative transfusions of donor specific antigenic material followed by preoperative immunosuppression with procarbazine hydrochloride and ATS. The observed effect of this combined pretransplant treatment of the recipient does not depend on donor-specific transfusions. The addition of third-party serum leads to kidney graft survival of equal extent. Furthermore it has been demonstrated that kidney graft survival after this combined pretransplant treatment schedule is not prolonged in one-haplotype mismatched littermate combinations.

This finding does not encourage direct clinical application of this pretreatment schedule for living related combinations.

The effect of donor drug pretreatment on kidney graft survival has been studied in the third publication. The effect of donor drug pretreatment with cyclophosphamide and methylprednisolone in man is disputed. A clear cut improved graft survival has been found after donor drug pretreatment with procarbazine hydrochloride and methylprednisolone in the dog. The clinical experience with this combination of drugs is restricted to only 5 patients. The significantly improved kidney graft survival after donor drug pretreatment with procarbazine hydrochloride and methylprednisolone observed in the presented experiments justifies a controlled clinical study.

Prolonged kidney graft survival induced by donor drug pretreatment could be abrogated in dogs by peroperative administration of donor antigens. A peroperative transfusion of donor blood or its constituents, as lymphocytes and leukocyte-free blood, did abrogate the beneficial effect of donor pretreatment on kidney graft survival. It has been hypothesized that the delayed graft rejection induced by donor drug pretreatment is mediated by transfer of minute amounts of cytotoxic drugs. These drugs paralyse graft rejection locally in the recognition phase of the immune response. In the light of this hypothesis the administration of donor antigenic material would bypass this immune paralysis by priming the immune system centrally for donor antigens. The hypothesis has been studied in the fourth publication. A significant decrease of the number of lymphocytes was found $5 \mathrm{hr}$ after the start of donor drug pretreatment. No specific depletion of $\mathrm{T}$ or B cells was observed. The effect of procarbazine hydrochloride and methylprednisolone donor drug pretreatment on immunological properties of peripheral blood leukocytes has been tested in this chapter. It was demonstrated that donor pretreatment leads to a depression of responsiveness and stimulation capacity of leukocytes from pretreated animals in mixed leukocyte cultures. This depression is completely reversed by purification by Lymphoprep density centrifugation and thereafter careful washing of these cells. The data obtained in the third and fourth publication support the hypothesis that small amounts of procarbazine hydrochloride and methylprednisolone or their derivates located in or on graft cells lead to prolongation of renal allograft survival after donor drug pretreatment.

In the final experimental study, publication 5, the combined effect of blood transfusions to the recipient and pretransplant treatment of the 
donor on kidney graft survival has been investigated. It was demonstrated in experiments performed in this study that the combination of a peroperative blood transfusion and donor drug pretreatment does not improve graft survival compared to either treatment alone. A transfusion might even abrogate the effect of donor pretreatment. Therefore clinical data obtained by donor pretreatment should be re-evaluated regarding the transfusion history of the recipients since until now little attention has been paid on whether or not the recipient of a drug pretreated kidney has been transfused. 


\section{Samenvatting}

De afstoting van een transplantaat door de ontvanger vormt het grootste probleem bij niertransplantaties. Door deze immunologische reactie verliest binnen 1 jaar na implantatie $30-40 \%$ van alle getransplanteerde nieren hun functie. De afstotingsreacties worden bestreden met behulp van immunosuppressiva. Aan het langdurige gebruik van deze medicijnen in soms hoge doses, zoals bij transplantatiepatiënten noodzakelijk is, zijn grote nadelen verbonden. Niet alleen hebben deze stoffen specifieke toxische bijwerkingen, het af weersysteem van de patient wordt in zijn geheel verzwakt waardoor het percentage infecties en maligniteiten toeneemt.

De typering voor antigenen waartegen afstotingsreacties gericht zijn ( $\mathrm{MHC}$ en $\mathrm{ABO}$ ) maakt het mogelijk donor-ontvanger combinaties samen te stellen met minimale verschillen voor deze antigenen, hetgeen tot een vermindering van het aantal afstotingsreacties heeft geleid. Dit blijkt uit de betere 1 jaars overleving van goed gematchde niertransplantaten. Ondanks de weefseltypering, blijft immunosuppressieve behandeling na transplantatie zelfs bij goed gematchde kadaver donor-ontvanger combinaties noodzakelijk. Het is duidelijk dat naar nieuwe wegen gezocht dient te worden die een verminderd gebruik van non-specifieke immunosuppressiva mogelijk maken.

In het eerste hoofdstuk van dit proefschrift wordt een kort historisch overzicht gegeven van de transplantatie chirurgie en de transplantatie immunologie. De literatuurgegevens betreffende het effect van bloedtransfusies en de voorbehandeling van de donor op de transplantaat overleving, de twee onderzoekslijnen van dit proefschrift, zijn in detail beschreven. De verrichte experimenten worden in hoofdstuk 2 ingeleid en de verkregen resultaten bediscussieerd.

Samenvattend kan worden geconcludeerd dat het de afgelopen jaren steeds duidelijker is geworden dat bloedtransfusies vóór transplantatie toegediend een gunstig effect hebben op de overlevingskans van het niertransplantaat. Men kan zelfs stellen dat het gunstige effect van bloedtransfusies heeft geleid tot de hoopvolle resultaten in de zestiger en begin zeventiger jaren, waardoor de niertransplantatie naast de dialyse een vaste plaats heeft verworven in de behandeling van de patiënt met een falende nierfunctie. Bloedtransfusies verminderen via nog onbekende weg de afweerreactie tegen het transplantaat. Hierbij dient echter te worden onderkend dat preoperatief toegediende transfusies ook het nadeel hebben dat de patiënt gesensitiseèrd kan raken. Sensibilisatie kan optreden tegen antigenen aanwezig in transplantaten van de potentiële donoren waardoor het moeilijker 
wordt voor de ontvanger een geschikt transplantaat te vinden. Het gevaar van sensibilisatie is niet aanwezig bij peroperatieve transfusies.

Gezien het feit dat een peroperatieve transfusie mogelijk zonder gevaar voor sensibilisatie de afstotingsreactie kan verminderen, is in deze studie de $\mathrm{klinisch}$ niet routinematig toegepaste peroperatieve transfusie dierexperimenteel getoetst. De hond is een geschikt proefdier gebleken daar met de mens vergelijkbare effecten, ten aanzien van verlenging van transplantaat overleving na multipele preoperatieve transfusies en sensibilisatie na multipele preoperatieve transfusies, zijn waargenomen.

In dit proefschrift wordt aangetoond dat een peroperatieve transfusie kan leiden tot een significant verlengde transplantaat overleving. In de eerste publicatie wordt tevens aangetoond dat deze verlenging alleen door een transfusie met onbehandeld 'totaal bloed' teweeg kon worden gebracht. Transfusies met leukocyten vrij bloed, met bestraald bloed en met lymphocytensuspensies waren niet effectief. Deze bevindingen maken het aannemelijk dat een peroperatieve bloedtransfusie met totaal bloed bij de mens een gunstig effect heeft op de transplantaat overleving. Het gunstige effect van bloedtransfusies bleek te kunnen worden versterkt door de ontvanger met immunosuppressiva te behandelen. Een bloedtransfusie 14 dagen voor transplantatie leidde namelijk tot betere overlevingsresultaten indien direct na transfusie gestart werd met immunosuppressie. Het is bekend dat patiënten die gedialyseerd worden een onderdrukt immuun systeem hebben. Mogelijk is deze onderdrukking essentieel om verbeterde transplantaat overlevingen na bloedtransfusies te verkrijgen.

In het volgende hoofdstuk, publicatie 2 , wordt het effect onderzocht. van een gecombineerde behandeling van de ontvanger met donor-specifieke of third party antigenen en immunosuppressiva preoperatief. De gebruikte immunosuppressiva bestonden uit een combinatie van procarbazine hydrochloride en ATS. Deze combinatie werkt synergistisch daar procarbazine hydrochloride bij voorkeur het centrale immuunapparaat attaqueert, terwijl ATS een groter effect heeft op de perifere lymfocyt. Aangetoond wordt dat een gecombineerde behandeling als boven beschreven leidde tot een verbeterde transplantaatoverleving. Er wordt geen verschil gevonden tussen de toediening van donor-specifiek dan wel third party antigeenmateriaal. Directe klinische toepasbaarbeid lijkt dit behandelingsmodel niet te hebben, daar bij de mens alleen transplantaties van organen van levende verwante donoren voor deze behandeling in aanmerking komen. Juist bij de verwante donor-ontvanger combinaties wordt géén verlenging van transplantaat overleving bij de hond gevonden.

Aan het effect van donor voorbehandeling op de overleving van niertransplantaten bij de mens wordt ernstig getwijfeld sinds enkele prospectieve studies geen duidelijk verschil in transplantatie overleving te zien gaven. In de derde publicatie wordt het gunstige effect van een donor voorbehandeling met procarbazine hydrochloride en methylprednisolone op de transplantaat overleving bij de hond aangetoond. In deze studie wordt de combinatie van procarbazine hydrochloride met methylprednisolone gebruikt, dit in tegen- 
stelling tot de bij de mens gebruikelijke combinatie van cyclophosphamide met methylprednisollone daar bij de hond reeds was aangetoond dat de eerstgenoemde combinatie een beter effect had. De ervaring met de combinatie procarbazine hydrochloride en methylprednisolone bij de mens is helaas zeer gering. De gunstige dierexperimentele resultaten met deze combinatie van geneesmiddelen lijken een gecontroleerde klinische studie te rechtvaardigen. De toediening van donorantigenen, met name donorbloed, donorlymphocyten, of donorleukocyten-vrij bloed, tijdens de operatie deed het gunstige effect van donor voorbehandeling teniet.

In de discussie van deze studie wordt de hypothese gesteld dat de verlenging van de transplantaat overleving na donor voorbehandeling teweeg wordt gebracht door een lokaal immunosuppressief effect van kleine hoeveelheden met de nier meegetransplanteerde immunosuppressiva. Deze veronderstelling wordt ondersteund door verdere gegevens verzameld in een in vitro studie (publicatie 4). $\mathrm{Na}$ toediening volgens het donor voorbehandelings schema, wordt het effect van procarbazine hydrochloride en methylprednisolone op perifere lymphocyten onderzocht. Op het moment dat nefrectomie zou plaats vinden, 5 uur na het begin van de donor voorbehandeling, wordt er een significant verlaagd aantal lymphocyten in het perifere bloed gevonden.

De ratio T-B lymphocyten blijkt niet gewijzigd. De lymfocyten van voorbehandelde dieren blijken zowel een verlaagde capaciteit om te responderen dan wel te stimuleren te hebben in de gemengde lymfocyten cultuur. Een normale lymfocyten response wordt verkregen nadat de lymphocyten van voorbehandelde dieren gezuiverd zijn door middel van Lymphoprep centrifugatie en vervolgens gewassen zijn. Hiermee wordt de aanwezigheid van immunosuppressiva op of in de cellen zeer aannemelijk.

In de vijfde publicatie wordt het effect van een gecombineerde behandeling met donor voorbehandeling en transfusies aan de ontvanger onderzocht. In dit onderzoek wordt de stelling getoetst dat deze gecombineerde behandeling niet zondermeer leidt tot een beter resultaat dan de afzonderlijke behandelingen. Aangetoond wordt dat de overleving van een transplantaat bij combinatie van donor voorbehandeling en peroperatieve transfusie niet verbetert ten opzichte van donor voorbehandeling op zich enerzijds en van een peroperatieve bloedtransfusie anderzijds. Een preoperatieve transfusie kan zelfs het effect van donor voorbehandeling teniet doen. $\mathrm{Bij}$ de beoordeling van de resultaten verkregen bij klinische studies met donor voorbehandeling lijkt het, gezien de resultaten van deze experimenten noodzakelijk de toediening van pre- en peroperatieve bloedtransfusies mede te betrekken. 


\section{References for chapter I and II}

Abouna, G.M.; Barabas, A.Z.; Pazderka, V.; Boyd, N.; Vetters, J.M.; Kinniburgh, D.W.; Lao, V.S.; Schlaut, J.; Kovithavongs, T.; Dossetor, J.B. (1977): Effect of pretreatment with multiple bloodtransfusions and with skin grafts on the survival of renal allografts in mongrel dogs. Transpl. Proc. IX: 265.

Albrechtsen, D.; Bratlie, A.; Kiss, E.; Solheim, B.G.; Thoresen, A.B.; Winther, N.; Thorsby, E. (1979): Significance of HLA-matching in renal transplantation. Transplantation 28: 280.

Alexander, J.W. (1980): Impact of transplantation on microbiology and infectious diseases. Transpl. Proc. XII: 593.

Barry, J.M.; Bennett, W.M. (1978): Primary cadaver kidney transplant survival after donor pretreatment with cyclophosphamide and methylprednisolone. Transplantation 26: 202.

Beaudoin, J.G.; Guttmann, R.D.; Morehouse, D.D.; Knaack, J.; Chassot, P.G. (1973): Improvement in cadaveric renal transplant survival. Arch. Surg. 107: 245 .

Berlinger, N.T.; Lopez, C.; Good, R.A. (1976): Facilitation or attenuation of mixed leukocyte culture responsiveness by adherent cells. Nature 260: 145 .

Billingham, R.E.; Krohn, P.L.; Medawar, P.B. (1951): Effect of cortisone on survival of skin homografts in rabbits. Br. Med. J. 1: 1157.

Blamey, R.W.; Knapp, M.S.; Burden, R.P.; Salisbury, M. (1978): Bloodtransfusion and renal allograft survival. $B r$. Med. $J .1: 138$.

Borel, J.F. (1976): Comparative study of in vitro and in vivo drug effects on cell-mediated cytotoxicity. Immunology 31:631.

Brent, L.; Opara, S.C. (1979): Specific unresponsiveness to skin allografts in mice. Transplantation 27: 120.

Briggs, J.D.; Canavan, J.S.F.; Dick, H.M.; Hamilton, D.N.H.; Kyle, K.F.; Macpherson, S.G.; Paton, A.M.; Titterington, D.M. (1978): Influence of HLA matching and bloodtransfusion on renal allograft survival. Transplantation 25: 80 .

Brom, H.L.E. (1980): Effects of donorpretreatment on canine renal allograft survival. Thesis, Leiden, The Netherlands.

Brynger, H.; Frisk, B.; Ahlmén, J.; Blohmé, I.; Sandberg, L. (1977): Bloodtransfusion and primary graft survival in male recipients. Scand. J. Urol. Nephrol. Suppl. 42: 76.

Bull, R.W.; Vriesendorp, H.M.; Obertop, H.; Bijnen, A.B; Jeekel, J.; de Gruyl, J.; Westbroek, D.L. (1978): Effect of prior third-party bloodtransfusions on canine renal allograft survival. Transplantation 26:249.

Buy-Quang, D.; Soulillou, J.P.; Fontenaille, Ch.; Guimbretière, J.; Guenel, J. (1977): Rôle bénéfique des transfusions sanguines et des grossesses dans la 
survie des allograffes rénales. La Nouvelle Presse Médicale 6: 3503.

Calne, R.Y. (1960): The rejection of renal homografts; inhibition in dogs by 6 mercaptopurine. Lancet $1: 417$.

Calne, R.Y. (1980): Transplant surgery: current status. Br. J. Surg. 67: 765.

Calne, R.Y.; Davis, D.R.; Medawar, P.; Wheeler, J.R. (1966): Effect of donor antigen on dogs with renal homotransplants. Transplantation 4: 742.

Calne, R.Y.; Rolles, K.; White, D.J.G.; et al. (1979): Cyclosporin A initially as the only immunosuppressant in 27 recipients of cadaveric renal transplants, Lancet 2: 1033 .

Calne, R.Y.; White, D.J.G.; Thiru, S.; Evans, D.B.; McMaster, P.; Dunn, D.C.; Craddock, G.N.; Pentlow, B.D.; Rolles K. (1978): Cyclosporin A in pa. tients receiving renal allografts from cadaver donors. Lancet $2: 1323$.

Carrel, A. (1902): La technique opératoire des anastomoses vasculaires et la transplantation des viscères. Lyon Méd 98: 859.

Cochrum, K.; Hanes, D.; Potter, D.; Perkins, H.; Amend, W. ; Vincenti, F.; Iwaki, Y.; Opelz, G.; Terasaki, P.; Feduska, N.; Salvatierra, O. (1981): Improved graft survival with donor specific transfusion pretreatment. Transpl. Proc. XIII: 190.

Chatterjee, S.N. (1979): Manual of renal transplantation. Springer Verlag, New York Inc.

Chatterjee, S.N.; Terasaki, P.I.; Fine, S.; Schulman, B.; Smith, R.; Fine, R.N. (1977): Pretreatment of cadaver dlonors with methylprednisolon in human renal allografts. Surg. Gynaec. Obstet. 145: 729.

Corry, R.J.; Patel, N.P.; West, J.C.; Schanbacher, B.A. (1980): Pretreatment of cadaver donors with cyclophosphamide and methylprednisolone: effect on renal transplant outcome. Transpl. Proc. XII: 348.

Corry, R.J.; West, J.C.; Hunsicker, L.G.; Schanbacher, B.A.; Lachenbruch, P.A. (1980): Effect of timing of administration and quantity of bloodtransfusions on cadaver renal transplant survival. Transplantation 30 : 425.

Cosimi, A.B. (1981): The clinical value of antilymphocyte antibodies. Transpl. Proc. XIII: 462.

Crawford, D.H.; Sweny, P.; Edwards, J.M.B.; Janossy, G.; Hoffbrand, A.V. (1981): Long-term T-cell-mediated immunity to Epstein-Barr virus in renal allograft recipients receiving cyclosporin $\mathrm{A}$. Lancet 1: 10 .

Dienst, S.G. (1977): Statewide Donor pretreatment study. Transpl. Proc. IX: 1597.

Dossetor, J.B.; MacKinnon, K.J.; Gault, M.H.; MacLean, L.D. (1967): Cadaver kidney transplants. Transplantation 5: 844.

Elkin, W.L.; Guttmann, R.D. (1968): Pathogenesis of a local Graft versus Host reaction: Immunogenicity of circulating host leucocytes. Science 159: 1250 .

Es, A.A. van; Balner, H. (1979): Effect of pretransplant transfusions on kidney allograft survival. Transpl. Proc. $X I: 127$.

Es, A.A. van; Marquet, R.L.; Rood, J.J. van; Balner, H. (1978): Influence of a single bloodtransfusion on kidney allograft survival in unrelated rhesus monkeys. Transplantation 26:325.

Es, A.A. van; Marquet, R.L.; Rood, J.J. van; Kalff, M.W.; Balner, H. (1977): Bloodtransfusions induce prolonged kidney allograft survival in rhesus monkeys. Lancet 1: 506 . 
Es, A.A. van; Terasaki, P.I. (1981): Bloodtransfusions and kidney allograft survival. Transpl. Proc. XIII: 1284.

Fabre, J.W.; Bishop, M.; Sen, T.; McKenzie, J.; Williams, K.A.; Denton, T.G.; Millard, P.R.; Morris, P.J. (1978): A study of three protocols of bloodtransfusion before renal transplantation in the dog. Transplantation 26: 94.

Fehrman, I.; Groth, C.G.; Lundgren, G.; Möller, E. (1980): Improved renal graft survival in transfused uremics. Transplantation $30: 324$.

Fish, J.C.; Sarles, H.E.; Remmers, A.; Townsend, C.M.; Bell, J.D.; Flye, M.W. (1981): Renal transplantation after thoracic duct drainage. Annals of Surgery 193: 752 .

Floersheim, G.L. (1969): A study of combined treatment with chemical immunosuppressants and anti-lymphocytic serum to prolong skin allograft survival. Transplantation 8: 392.

Floersheim, G.L. (1973): Induction of unresponsiveness to skin and heart allografts in mice by a synergistic treatment with procarbazine, antilymphocyte serum and donor-type cells. Transplantation 15: 195.

Floersheim, G.L.; Taub, R.N.; Phillips-Quagliata, J.M.; Levey, R.H. (1970): Induction of tolerance to skin homografts with a methylhydrazine derivate. Synergism with anti-lymphocytic serum and morphologic responses of the lymphoid system. Agents and Actions 1: 115 .

Fuller, T.C.; Delmonico, F.L.; Cosimi, A.B.; Huggins, C.E.; King, M.; Russell, P.S. (1977): Effects of various types of RBC transfusions on HLA alloimmunization and renal allograft survival. Transpl. Proc. IX: 117.

Garriques, H.J ; Romero, P.; Hellström, I.; Hellström, K.E. (1981): Adherent cells (macrophages?) in tumor-bearing mice suppress MLC responses. $\mathrm{Cel}$ lular Immunology 60: 109.

Gordon, M.Y.; Singer, J.W. (1979): Selective effects of Cyclosporin A on colony forming lymphoid and myeloid cells in man. Nature 279:433.

Groth, C.G. (1972): Landmarks in clinical renal transplantation. Surg. Gynaecol Obstet. 134: 323.

Groth, C.G. (1981): The value of ALG and ATG in clinical renal transplantation - Recent European Experience. Transpl. Proc. XIII: 460.

Guttmann, R.D.; Beaudoin, J.G.; Morehouse, D.D. (1973): Reduction of immunogenicity of human cadaver renal allografts by donorpretreatment. Transpl. Proc. V: 663.

Guttmann, R.D.; Beaudoin, J.G.; Morehouse, D.D.; Klassen, J.; Knaack, J.; Jeffery, J.; Chassot, P.G.; Abbou, C.C. (1975): Donor pretreatment as an adjunct to cadaver renal allotransplantation. Transpl. Proc. VII: 117.

Guttmann, R.D.; Morehouse, D.D.; Meakins, J.L.; Klassen, J.; Knaack, J.; Beaudoin, J.G. (1978): Donorpretreatment in an unselected series of cadaver renal allografts. Kidney International 13 suppl. 8: 99.

Guttmann, R.D.; Morehouse, D.D.; Meakins, J.L.; Milne, C.A.; Knaack, J. (1980): Donorpretreatment as an adjunct to cadaveric renal transplantation - update 1979. Transpl. Proc. XII: 341.

Halasz, N.A.; Seifert, L.N.; Rosenfield, H.A.; Orloff, M.J.; Stier, H.A. (1966): The effects of antigen overloading on survival of renal allografts. Proc. Soc. Exp. Biol and Med. 123: 924.

Harder, F.; Floersheim, G.L.; Jeekel, J.; Van der Linden, C.J.; Mihatsch, J.; Rüedi, T.; Tondelli, P. (1979): Prolongation of canine renal allografts: 
Plasma or Liver instead of bloodtransfusions combined with preoperative non-specific immunosuppression. Transpl. Proc. XI: 978.

Helling, T.S.; Alleman, R.E.; Thomas, C.Y.; Moore, M.D.; Koontz, P.G. (1980): Prevention and management of urologic complications following renal transplantation. Transpl. Proc. XII: 695.

Hourmant, M.; Soulillou, J.P.; Bui-Quang, D. (1979): Beneficial effect of bloodtransfusion. Role of the time interval between the last transfusion and transplantation. Transplantation 28: 40.

Hume, D.B.; Merrill, J.P.; Miller, B.F.; Thorn, G.W. (1955): Experiences with renal homotransplantation in the human: report of nine cases. J. Clin. Invest. 34: 327.

Hunsicker, L.G.; Oei, L.S., Freeman, R.M.; Thompson, J.S.; Corry, R.J. (1979): Effect of bloodtransfusions on cadaver renal allograft survival. Transpl. Proc. XI: 156.

Husberg, B.; Lindergard, B.; Lindhom, T.; Löw, B. (1977): Blood transfusion and kidney transplantation. Scand. J. Urol. Nephrol. suppl. 42:73.

Jacobs, C.; Brunner, F.P.; Brynger, H.; Chantler, C.; Donckerwolcke, R.A.; Hathway, R.A.; Kramer, P.; Selwood, N.H.; Wing, A.J. (1981): Malignant diseases in patients treated by dialysis and transplantation in Europe. Transpl. Proc. XIII: 729.

Jeekel, J.; Linden, C.J. v.d.; Vegt, P.A.; Buurman, W.A.; Harder, F.; Persijn, G. (1980): Modification of kidney graft survival in dog and man by preoperative transfusion to the donor. Proc. EDTA 17: 457.

Jeffery, J.R.; Downs, A.R.; Grahame, J.W.; Lye, C.; McKenzie, J.K.; Ramsey, E.; Thomson, A.E.; Walker, R. (1978): Operation-day blood-transfusions and renal transplantation. Lancet 1: 662 .

Jeffery, J.R.; Downs, A.; Grahame, J.W.; Lye, C.; Ramsey, E.; Thomson, A.E. (1978): Failure of bloodtransfusions to improve cadaveric renal allograft survival. Transplantation 25: 344 .

Jeffery, J.R.; Guttmann, R.D.; Charpentier, B. (1976): In vitro monitoring of cadaver kidney donorpretreatment by lymphocyte culture. Clin. exp. Immunology 25: 437.

Jonasson, O.; Moses, V. (1981): Factors influencing first cadaver renal allograft survival. Transpl. Proc. XIII: 44.

Joysey, V.C.; Roger, J.H.; Evans, D.B., Herbertson, B.M. (1977): Differential kidney graft survival associated with interaction between recipient $A B O$ group and pretransplant bloodtransfusion. Transplantation 24: 371 .

Keown, P.A.; Descamps, B. (1979): Improved renal allograft survival after bloodtransfusion: A non-specific, erythrocyte-mediated immunoregulatory process? Lancet $1: 20$.

Küss, R.; Teinturier, J.; Milliez, P. (1951): Quelques essais de greffe de rein chez l'homme. Mém. Acad. Chir. 77: 755.

Laughter, A.H.; Rice, L.; Twomey, J.J. (1981): Suppression of lymphocytes responses by monocytoid cells does not require cell-cell contact. Cellular Immunology 60: 440 .

Lee, D.B.N.; Prompt, C.A.; Tyler Upham, A.; Kleeman, C.R. (1977): Medical complications of renal transplantation. Graft and Infectious complications in recipient. Urology suppl. 9:6.

Linn, B.S. (1966): Renal allografts and donor spleen cells: Survival according to schedule of infuction. Annals of Surgery 164: 233. 
MacDonald, A.S.; Chan, C.C.; Falvey, C.F. (1971): Use of procarbazine hydrochloride (Natulan) and procarbazine hydrochloride and azathioprine in canine renal allografts. Transplantation 11: 103.

McDonald, J.C ; Vaughn, W.; Filo, R.S.; Picon, G.M.; Niblack, G.; Spees, E.K.; Williams, G.M. (1981): Cadaver donor renal transplantation by centers of the Southeastern organ procurement foundation. Annals of Surgery 193: 1 .

McHenry, M.C.; Braun, W.E.; Popowniak, K.L.; Banowksy, L.H; Deodhar, S.D. (1976): Septicemia in renal transplant recipients. Urologic clinics of North America 3: 647.

Medawar, P.B. (1944): The behaviour and fate of skin autografts and skin homografts in rabbits. J. Anat. 78: 176.

Michon, L.; Hamburger, J.; Oeconomos, N.; Delinotte, P.; Richet, G.; Vaysse, G.; Antoine, B. (1953): Une tentative de transplantation rénale chez l'homme; aspects médicaux et biologiques. Presse Med. 61: 1419.

Mookerjee, B.K.; Ballard, J. (1979): Functional characteristics of monocytes. Transplantation 27: 59.

Monaco, A.P.; Campion, J-P.; Kapnick, S.J. (1977): Clinical use of antilymphocyte globulin. Transpl. Proc. IX: 1007 .

Murphy, J.F.; McDonald, F.D.; Dawson, M.; Reite, A.; Turcotte, J.; Fekety, R. (1976): Factors affecting the frequency of infection in renal transplant recipients. Arch. Intern. Med. 136: 670 .

Murray, J.E.; Merrill, J.P.; Dammin, G.J.; Dealy, J.B.; Walter, C.W.; Brooke, M.S.; Wilson, R.E. (1960): Study on transplantation immunity after total body irradiation: clinical and experimental investigation. Surgery 48: 272.

Najarian, J.S.; Sutherland, D.E.R.; Ferguson, R.M.; Simmons, R.L.; Kersey, J.; Mauer, S.M., Slavin, S.; Kin, T.H. (1981): Total lymphoid irradiation and kidney transplantation: A clinical experience. Transpl. Proc. XIII: 417.

Obertop, H.; Bijnen, A.B.; Vriesendorp, H.M., Westbroek, D.L. (1978): Prolongation of renal allograft survival in DLA tissuetyped beagles after third party bloodtransfusions and immunosuppressive treatment. Transplantation 26: 255.

Oei, L.S.; Thomson, J.S.; Corry, R.J. (1979): Effect of bloodtransfusions on survival of cadaver and living related renal transplantations. Transplantation 28: 482 .

Opelz, G. (1979): Manual of Renal transplantation. Springer-Verlag.

Opelz, G.; Graver, B.; Terasaki, P.I. (1981): Induction of high kidney graft survival by multiple transfusions. Lancet 1: 1223.

Opelz, G.; Mickey, M.R.; Terasaki, P.I. (1972): Identification of unresponsive kidney-transplant recipients. Lancet 1: 868 .

Opelz, G.; Senger, D.P.S.; Mickey, M.R.; Terasaki, P.I. (1973): Effect of bloodtransfusions on subsequent kidney transplants. Transpl. Proc. V: 253.

Opelz, G.; Terasaki, P.I. (1974): Poor kidney-transplant survival in recipients with frozen-blood transfusions or no transfusions. Lancet 2: 696 .

Opelz, G.: Terasaki, P.I. (1978): Improvement of kidney-graft survival with increased numbers of bloodtransfusions. N. Eng. J. Med. 299: 799.

Opelz, G.; Terasaki, P.I. (1980): Dominant effect of transfusions on kidney graft survival. Transplantation 29: 153. 
Opelz, G.; Terasaki, P.I. (1981): Importance of preoperative (not peroperative) transfusions for cadaver kidney transplants. Transplantation 31: 106 . Oriol, R.; Opelz, G.; Chun, C.; Terasaki, P.I. (1980): The Lewis system and kidney transplantation. Transplantation 29: 397.

Paul, L.C.; Es, L.A. van; Rood, J.J. van; Leeuwen, A. van; Brutel de la Rivière, G.; Graeff, J. de (1979): Antibodies directed against antigens on the endothelium of peritubular capillaries in patients with rejecting renal allografts. Transplantation 27: 175.

Pawelec, G.; Brons, G. (1978): Modification of lymphocyte responsiveness in vitro by carrageenan compared with colloidal silica and depletion of surface adherent cells. Clin. exp. Immunol. 31:426.

Perkins, H.A.; Salvatierra, O. (1977): Correlation of renal allograft survival with previous blood transfusions. Transpl. Proc. IX: 209.

Persijn, G.G., Cohen, B.; Lansbergen Q.; Rood, J.J. van (1979): Retrospective and prospective studies on the effect of bloodtransfusions in renal transplantation in the Netherlands. Transplantation 28: 396.

Persijn, G.G.; Gabb, B.W.; Leeuwen, A. van; Nagtegaal, A.; Hoogeboom, J.; Rood, J.J. van (1978): Matching for HLA-antigens of A, B, and Dr Loci in renal transplantation by Eurotransplant. Lancet 1: 1278 .

Polesky, H.F., McCullough, J.J.; Yunis, E.; Helgeson, M.A.; Andersen, R.C.; Simmons, R.L.; Najarian, J.S. (1977): The effects of transfusion of frozenthawed deglycerolized red cells on renal graft survival. Transplantation 24: 449.

Prompt, C.A.; Lee, D.B.N.; Tyler Upham, A.; Kleeman, C.R. (1977): Medical complications of renal transplanation. Part II Non infectious complications in recipient. Urology 9:6.

Proud, G.; Shenton, B.K.; Smith, B.M. (1979): Bloodtransfusion and renal transplantation. Br. J. Surg. $66 ; 678$.

Rapaport, F.T. (1981): Perspectives in Transplantation. Transpl. Proc. XIII: 6.

Rashid, A.; Sengar, D.P.S. (1978): Pretransplant blood-transfusions on allograft survival. Letter to the Editor. Lancet 1:825.

Rood, J.J. van; Leeuwen, A. van; Bruning, J.W. (1967): The relevance of leukocyte antigens for allogeneic renal transplantation. d. Clin. Path. 505.

Rood, J.J. van; Leeuwen, A. van; Persijn, G.G.; Lansbergen, Q.; Goulmy, E.; Termytelen, A.; Bradley, B.A. (1977): HLA compatibility in clinical transplantation. Transpl. Proc. $I X: 459$.

Rood, J.J. van; Persijn, G.G.; Leeuwen, A. van; Goulmy, E.; Gabb, B.W. (1979): A new strategy to improve kidney graft survival: the induction of CML non-responsiveness. Transpl. Proc. XI: 736 .

Salaman, J.R. (1978): Letter to the Editor. Lancet 1: 494.

Salvatierra, O.; Amend, W.; Vincenti, F.; Potter, D.; Stoney, R.; Duca, R.; Feduska, N. (1981): 1.500 Renal transplants at one center: Evolution of a strategy for optimal success. Am. J. Surgery 142: 14.

Schilfgaarde, $\mathbb{R}_{\text {. van }}(1978)$ : Uremic escape of renal allograft rejection. Thesis, Leyden. The Netherlands.

Schmidt, P.; Kopsa, H.; Balcke, P.; Zazgornik, J.; Mayr, W.R.; Wagner, O.; Piza, F. (1978): Verlängerte Funktionsdauer von Nierentransplantaten nach Mehrfachtransfusionen. Wien. Klin. Wochenschr. 90:193. 
Schwartz, R.; Dameshek, W. (1960): The effects of 6 mercaptopurine on homograft reactions. J. Clin. Invest. 39: 952.

Slavin, S.; Strober, S.; Fuks, Z.; Kaplan, H.S. (1977): Induction of specific tissue transplantation tolerance using fractionated total $\| y m p h o i d$ irradiation in adult mice: long-term survival of allogeneic bone marrow and skin grafts. J. Exp. Med. 146: 34 .

Slavin, S.; Yatziv, S.; Zan Bar, I.; Fuks, Z.; Kaplan, H.S.; Strober, S. (1980): Non specific and Specific immunosuppression by total lymphoid irradiation (TLI). Immunology 80: 1160.

Solheim, B.G.; Flatmark, A.; Halvorsen, S.; Jervell, J.; Pape, J.; Thorsby, E. (1980): Effect of bloodtransfusions on renal transplantation. Transplantation 30: 281 .

Soulillou, J.P.; Baron, D.; Rouxel, A.; Guenel, J. (1979): Steroid-Cyclophosphamide pretreatment on kidney allograft donors. A control study. Nephron. 24: 193.

Spees, E.K.; Vaughn, W.K.; Williams, G.M.; Filo, R.S.; McDonald, J.C.; Mendez-Picon, G.; Niblack, G. (1980): Effects of bloodtransfusion on cadaver renal transplantation. Transplantation 30:455.

Starzl, T.E. (1978): Personel reflections in transplantation. Surg. Clin. North. America 58: 879 .

Starzl, T.E.; Marchioro, T.L.; Waddell, W.R. (1963): The reversal of rejection in human renal homografts with subsequent development of homograft tolerance. Surg. Gynaecol. Obstet. 117:385.

Starzl, T.E.; Weil, R.; Koep, L.J.; McCalmon, R.T.; Terasaki, P.I.; Iwaki, Y.; Schröter, G.P.J.; Franks, J.J.; Subryan, V.; Halgrimson, C.G. (1979): Thoracic duct fistula and renal transplantation. Ann. of Surgery 190: 474.

Stiller, C.R.; Lockwood, B.L.; Sinclair, N.R.; Ulan, R.A.; Sheppard, R.R.; Scharpe, J.A.; Hayman, P. (1978): Beneficial effect of operation-day blood-transfusions on human renal-allograft survival. Lancet 1: 169.

Storb, R.; Floersheim, G.L.; Weiden, P.L.; Graham, T.C.; Kolb, H.J.; Lerner, K.G.; Schroeder, M.L.; Thomas, E.D. (1974): Effect of prior bloodtransfusions on marrow grafts: abrogation of sensitization by procarbazine and antithymocyte serum. $J$. of Immunology 112: 1508 .

Ting, A.; Morris, P.J. (1980): Powerful effect of HL-Dr matching on survival of cadaveric renal allografts. Lancet $2: 282$.

Traeger, J.; Touraine, J.L.; Archimbaud, J.P.; Malik, M.C.; Dubernard, J.M. (1978): Thoracic duct drainage and antilymphocyte globulin for renal transplantation in man. Kidney International 13 suppl. 8: 103.

Ullmann, E. (1902): Experimentelle Nierentransplantation. Wien. Klin. Wochenschr. 15: 281707.

Varkarakis, M.J.; Sampson., D.; Brede, H.D.; Murphy, G.P. (1972): The immunosuppressive effect of procarbazine hydrochloride in canine renal allografts. Transplantation 13: 42 .

Vegt, P.A.; Buurman, W.A.; Van der Linden, C.J.; Daemen, A.J.J.M.; Greep, J.M.; Jeekel, J. (1981): Cell mediated cytotoxicity towards kidney epithelial cells. Transplantation; in press.

Voronoy, U. (1936): Sobre el bloqueo del aparáto reticuloendotelial del hombre en algunas formas de intoxicación por el sublimado y sobre la transplantación del rinon cadavérico como metodo de tratamiento de la anuaria consecutiva a aquella intoxicación. Siglo Méd. 97: 296. 
White, D.J.G.; Plumb, A.M.; Pawelec, G.; Brons, G. (1979): Cyclosporin A: an immunosuppressive agent preferentially active against proliferating $\mathrm{T}$ cells. Transplantation 27: 55.

Williams, K.A.; Ting, A.; French, M.E.; Oliver, D.; Morris, P.J. (1980): Peroperative blood-transfusions improve cadaveric renal-allograft survival in non-transfused recipients. A prospective controlled clinical trial. Lancet 1: 1104.

Williamson, C.S. (1923): Some observations on the length of survival and function of homogenous kidney transplants. Preliminary report. J. Urol. $X: 275$.

Wilson, R.E.; Rippin, A.; Dagher, R.K.; Kinnaert, P.; Busch, G.J. (1969): Prolonged canine renal allograft survival after pretreatment with solubilized antigen. Transplantation 7: 360 .

Zighelboim, J.; Lichtenstein, A.; Benjamin, D. (1981): Response of normal subjects to mitogens. Clinical immunology and immunopathology 19: 406.

Zimmerman, C.E.; Busch, G.J.; Stuart, F.P.; Wilson, R.E. (1968): Canine renal homografts after pretreatment with subcellular splenic antigens. Surgery $63: 437$.

Zincke, H.; Woods, J.E. (1974): Attempted immunological alterations of canine renal allograft donors. Transplantation 18: 480.

Zincke, H.; Woods, J.E. (1977): Donor pretreatment in cadaver renal transplantation. Surg., Gynaecol. Obstet. 145: 183.

Zincke, H.; Wood, J.E.; Khan, A.U.; Holley, K.E.; Leary, F.J. (1978): Immunological donor pretreatment in combination with pulsatile preservation in cadaveric renal transplantation. Transplantation 26: 207. 


\section{Publications presented in this thesis}

\section{Publication 1}

The effect of bloodtransfusions on canine renal allograft survival. Linden, C.J. v.d.; Buurman, W.A.; Vegt, P.A.; Greep, J.M. and Jeekel, J. Transplantation: in press.

\section{Publication 2}

Preoperative Immunosuppression With Antithymocyte Serum and Procarbazine: Effect on Kidney Graft Survival in Dogs After Donor ThirdParty Antigen Administration. Linden, C.J. v.d.; Harder, F.; Buurman, W.A.; Fabricant, A.S.; Greep, J.M.; Jeekel, J. Transpl. Proc. XII: 352, 1980 .

\section{Publication 3}

Prolongation of Canine Renal Allograft Survival. A Study on the effect of Donor Pretreatment. Linden, C.J. v.d.; Buurman, W.A.; Vegt, P.A.; Greep, J.M.; Jeekel, J. Transplantation 30: 132, 1980.

\section{Publication 4}

A Study on the Mechanism of donor pretreatment. Effect of Procarbazine hydrochloride and Methylprednisolone on immunocompetent cells. Linden, C.J. v.d.; Buurman, W.A.; Vegt, P.A.; Greep, J.M.; Jeekel, J. Transplantation $32: 24,1981$.

\section{Publication 5}

The effect of transfusions and donorpretreatment on canine renal allograft survival. Linden, C.J. v.d.; Buurman, W.A.; Vegt, P.A.; Bruins Slot, H.; Greep, J.M.; Jeekel, J. Journal of Surgical Research: in press. 


\section{The effect of blood transfusions on canine renal allograft} survival

\section{Summary}

In this study significantly prolonged canine renal allograft survival has been demonstrated after transfusion of $100 \mathrm{ml}$ third party whole blood given peroperatively. Peroperative transfusions of third party leukocyte-free blood or pure lymphocyte cell suspensions did not influence graft survival. Furthermore no improvement in graft survival has been found after a peroperative transfusion of irradiated whole blood $(2,500 \mathrm{rad})$. These data suggest that delayed graft rejection after blood transfusions can only be expected after the administration of whole blood.

The role of competent lymphocytes in whole blood is questionable, since a transfusion of irradiated whole blood in combination with non irradiated lymphocytes did not lead to prolonged graft survival.

Immunosuppression of the recipient directly after transfusion seems to be essential to induce the beneficial effect of blood transfusions. This has been demonstrated for a transfusion of whole blood 14 days before transplantation. A single transfusion of $100 \mathrm{ml}$ whole blood 14 days before transplantation could effectively prolong graft survival if immunosuppression with azathioprine and prednisone was started on the day of transfusion. No improvement in graft survival has been found with such a transfusion if preoperative immunosuppression has been omitted.

\section{Introduction}

Blood transfusions can enhance graft survival, providing a strong argument in favour of a deliberate transfusion policy for potential recipients of cadaver kidney grafts $(1,2)$.

However, the risk of sensitization of transplantation candidates has always been a serious objection to multiple preoperative transfusions. Peroperative transfusions do not sensitize the recipient, however the effect. of such a transfusion on kidney graft survival in man is still a matter of debate. Positive results with peroperative transfusions have been reported $(3,4,5)$, but other investigators could not confirm these data $(6,7,8,9)$.

Recently Williams et al. (10) reported a significant effect of 2 units of whole blood given peroperatively on kidney graft survival in a prospective clinical study. This report led to a further analysis of transplantations 
performed during 1978-1979 in 65 North American centers after peroperative transfusions. No influence of peroperative transfusions has been reported in this retrospective study (11).

Little data exist on the effect of single blood transfusions given during or shortly before transplantation in experimental animals. Van Es reported prolongation of kidney graft survival after one blood transfusion given within $24 \mathrm{hr}$ of transplantation in a monkey model.

Accelerated rejection was not observed in animals transfused during transplantation, whereas one blood transfusion 14 days before transplantation induced earlier rejection in a number of animals (12). In the dog improved graft survival after multiple preoperative blood transfusions as well as sensitization with decreased graft survival has been reported $(13,14,15,16)$. Information on the effect of peroperative transfusions on kidney graft survival is lacking in this animal.

In this study we report the effect of a single blood transfusion before transplantation and the effect of peroperative transfusion of different blood products on renal allograft survival in the dog. A significant improvement in graft survival has been observed with a peroperative transfusion of whole blood. Prolonged kidney graft survival could not be established by any other peroperative transfusion.

A single transfusion of whole blood 14 days before transplantation led to considerable prolongation of graft survival only, if immunosuppression was started on the day of transfusion. This observation indicates the importance of immunosuppression in inducing the beneficial effect of blood transfusions on kidney graft survival.

\section{Materials and methods}

Dogs. Male and female mongrel dogs varying in weight from 10 to $15 \mathrm{~kg}$ body wt were used. Transplantations have been performed in unmatched donor-recipient combinations.

Kidney-transplantation. Anesthesia consisted of fentanyl-base, Na-pento barbital and $\mathrm{O}_{2} / \mathrm{N}_{2} \mathrm{O}$ gas. Left or right donor kidneys were transplanted into the right iliac fossa. Bilateral nephrectomy was performed at the end of operation. The kidneys were flushed immediately after harvesting with 100 to $500 \mathrm{ml}$ of cold Euro-Collins solution. The total ischemic time was always shorter than 45 minutes. Postoperatively all dogs received $2 \mathrm{mg}$ of azathioprine per $\mathrm{kg}$ body wt and $2 \mathrm{mg}$ of prednisone per $\mathrm{kg}$ body wt per day for the first 10 days i.v., thereafter every other day. Complete graft rejection was taken as the day on which the serum creatinine rose above $1,000 \times 10^{-6}$ mole/liter. Autopsy and histology were performed routinely.

Blood transfusions. Peroperative transfusions were given i.v. immediately after venous and arterial anastomoses had been established. All transfusions consisted of freshly prepared heparinized cell suspensions. Blood was drawn from a third party mongrel dog. Whole blood was washed 
twice with saline and consisted of all bloodcomponents except plasma. Leukocyte-free blood was prepared by flushing $100 \mathrm{ml}$ fresh blood over a leukocyte filtration column (Red Cross Transfusion Service of The Netherlands). More than $99.99 \%$ of the original number of leukocytes was removed using this method. The total number of leukocytes decreased from an average of $7 \times 10^{6}$ cells $/ \mathrm{ml}$ to an average of 99 cells $/ \mathrm{ml}$. Leukocyte-free blood consisted of erythrocytes, $50 \pm 10 \%$ of the original thrombocytes and $50 \pm 15 \%$ of the original plasma protein. Lymphocytes were prepared with gradient cell separation by Lymphoprep (Nyegaard, Oslo, Norway) and carbonyl-iron treatment of peripheral blood. Peripheral blood was heparinized, diluted 1:1 with Hanks-balanced salt solution. To remove phagocytizing cells a carbonyl-iron suspension of $120 \mathrm{mg} / \mathrm{ml}$ in phosphate buffered saline (SF, carbonyl-iron G.A.F., Corp., New York, USA) was added to 10 volume parts of the blood Hanks mixture and incubated for 20 minutes at $37 \mathrm{C}$. This technique removes $85 \%$ of the phagocytizing cells, as tested with latex particels. Three parts of the blood-Hanks mixture were layered onto one part of Lymphoprep $\left(\delta=1.077 \mathrm{~g} / \mathrm{cm}^{3}\right)$. The tubes were spun for 20 minutes, $20-22 \mathrm{C}$ at $1,000 \mathrm{~g}$. The interface was carefully removed and washed twice with Hanks-balanced salt solution. Irradiated blood and lymphocytes received a dose of $2,500 \mathrm{rad}, 250 \mathrm{kV}$ x-rays.

Experimental groups. Kidney transplantations have been performed in 9 experimental groups. All animals received postoperative immunosuppression.

Experiment A: (12 dogs) $100 \mathrm{ml}$ fresh third party whole blood was transfused peroperatively.

Experiment B: (10 dogs) $100 \mathrm{ml}$ fresh third party leukocyte-free blood was transfused peroperatively.

Experiment C: (12 dogs) $2.9 \pm 0.7 \times 10^{8}$ lymphocytes were transfused peroperatively. This amount of cells equals the average number of lymphocytes present in $100 \mathrm{ml}$ whole blood.

Experiment D: ( 8 dogs) $100 \mathrm{ml}$ irradiated $(2,500 \mathrm{rad})$ fresh third party whole blood was transfused peroperatively.

Experiment E: (9 dogs) $100 \mathrm{ml}$ irradiated $(2,500 \mathrm{rad})$ fresh whole blood was transfused peroperatively. $3.5 \pm 0.9 \times 10^{8}$ non-irradiated lymphocytes of the same donor were added to the transfusate of irradiated whole blood.

Experiment $F:(11$ dogs) Control animals.

Experiment G: ( 8 dogs) $100 \mathrm{ml}$ fresh third party whole blood was transfused 14 days before transplantation.

Experiment $\mathrm{H}$ : (10 dogs) $100 \mathrm{ml}$ fresh third party whole blood was transfused 14 days before transplantation. Preoperative immunosuppression consisting of $2 \mathrm{mg}$ per $\mathrm{kg}$ body wt azathioprine and $2 \mathrm{mg}$ per $\mathrm{kg}$ body wt prednisone daily was started on the day of transfusion (day -14).

Experiment I: ( 7 dogs) Preoperative immunosuppression consisting of $2 \mathrm{mg}$ per $\mathrm{kg}$ body wt azathioprine and $2 \mathrm{mg}$ per $\mathrm{kg}$ body wt prednisone was started 14 days before transplantation (day -14). 


\section{Results}

Table 1 and table 2 depict the graft survival time in the different experimental groups. Technical failures and deaths caused by diseases other than rejection have been excluded. A beneficial effect on graft survival of whole blood given during transplantation was established in this model (group A). A mean graft survival of 21 days was found in these recipients. This is a significant prolonged survival compared to the mean survival time of control animals, 12.6 days (group $F$ ). As expected accelerated rejection was not observed after a peroperative transfusion. Different blood products were tested in the same experimental model (group B, C, D and E) to investigate the role of lymphocytes present in whole blood.

In group B, 10 dogs were injected with $100 \mathrm{ml}$ leukocyte-free blood. None of these animals survived longer than the controls (group F). In group $\mathrm{C}, 12$ dogs were transfused with a suspension of lymphocytes during transplantation. Although 2 animals survived longer than any of the control animals, significant prolongation of graft survival due to such a transfusion could not be established. A transfusion of irradiated whole blood during transplantation (group D) did not influence kidney graft survival. These data suggested that cells able to proliferate, in combination with other blood components, are essential for prolongation of kidney graft survival after peroperative transfusions in this model. A crucial role of lymphocytes in this event could not be established. In experiment $\mathrm{E}, 9$ dogs received irradiated whole blood in combination with non-irradiated lymphocyte cells of the same donor during transplantation. None of the dogs in this group survived longer than the control animals (group F).

In order to investigate the role of postoperative immunosuppression which started immediately after these peroperative transfusions, three additional experiments have been performed.

A single transfusion of whole blood given 14 days before transplantation led to increased survival in only 2 dogs (group G). The mean graft survival was not significantly different from the control group (group F).

An inconsistent but striking effect of a preoperative transfusion of whole blood was observed however if the animals received immunosuppression immediately after transfusion. In group $H$, dogs received a transfusion of whole blood 14 days before transplantation. Immunosuppression with $2 \mathrm{mg}$ per $\mathrm{kg}$ body wt azathioprine and $2 \mathrm{mg}$ per $\mathrm{kg}$ prednisone i.v. daily started the day of transfusion. Six out of ten dogs survived longer than the animals which received only preoperative immunosuppression (group I). Immunosuppression of the recipient directly after transfusion seems therefore to add to the beneficial effect of blood transfusions on kidney graft survival in the dog. 


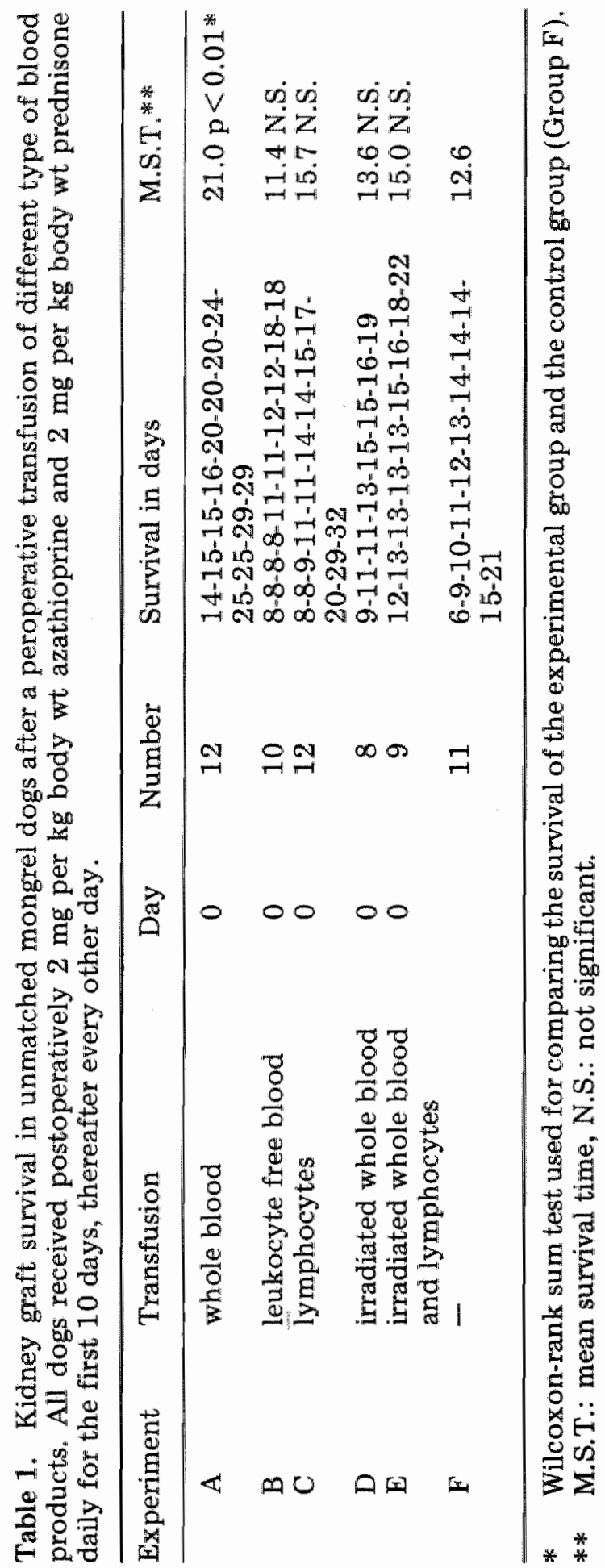




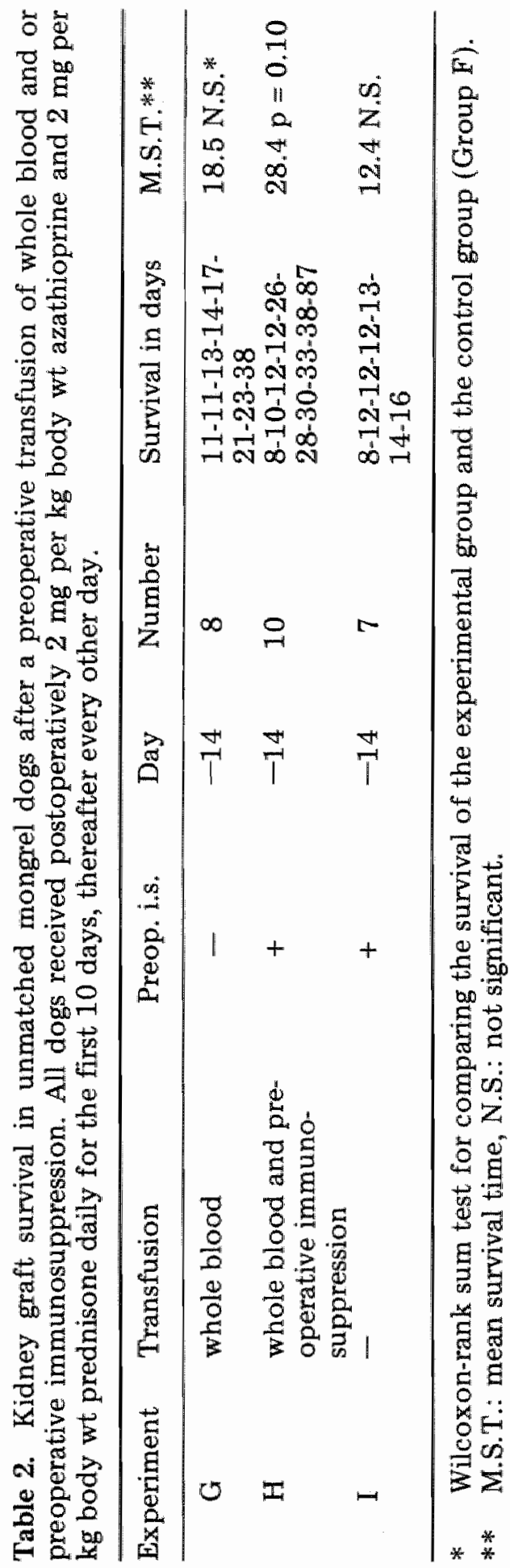




\section{Discussion}

These experiments show a beneficial effect of a whole blood transfusion given during transplantation on kidney graft survival in unmatched donorrecipient combinations in the dog. This finding supports recent data in man that peroperatively given whole blood transfusions may have a positive effect on kidney graft survival (10).

A policy of intentional transfusions of whole blood during transplantation has to be seriously considered, especially since these transfusions do not sensitize the recipient.

Transfusions of different blood products other than whole blood may be uneffective as shown in this study. Peroperative transfusions with leukocytefree blood and lymphocyte cell syspensions gave poor results, although two out of twelve dogs, receiving a lymphocyte cell suspension during transplantation survived longer than controls.

The ineffectiveness of leukocyte-free blood found in this study is in accordance with results obtained in man with peroperative transfusions of this type (2). Preoperative transfusions with leukocyte-free blood and lymphocyte cell suspensions in monkeys led to both delayed and accelarated rejection (12). The fact that graft survival obtained after peroperative transfusions of irradiated blood did not differ from controls led to the suggestion that cells capable of proliferation are important in the induction of kidney graft survival extension after blood transfusions. In this study it could not be proven that lymphocytes are the responsible cells for the transtumor effect since a peroperative transfusion of irradiated blood to which non-irradiated lymphocytes of the same donor had been added did not prolong kidney graft survival. It has to be noted of course that irradiated blood with non-irradiated lymphocytes does not equal whole blood. Irradiation will likely damage cell membranes, which may lead to a decreased circulation time of all transfused cells in the host. Furthermore the admixed transfusate lacks the presence of non-irradiated phagocytizing leukocytes.

In this study a role for immunosuppression after blood transfusion has been found. Prolonged kidney graft survival after a single preoperative blood transfusion has only been observed after direct immunosuppression of the recipient. An important difference exists between the beneficial effects on graft survival of peroperative blood transfusions and of preoperative blood transfusions.

Graft survival extension after peroperative blood transfusions has been constantly found in all animals tested whereas preoperative transfusions led to control graft survival in only a number of the transfused animals. This might be caused by a slight sensitization effect of preoperative transfusions in these animals.

A hypothesis in the literature to explain the beneficial effect of blood transfusion has been an impairment of host mononuclear phagocytic function by endocytosis of infused erythrocytes $(17,18)$. It seems unlikely that this mechanism is involved in the prolongation of graft survival in this model 
since leukocyte-free blood as well as irradiated whole blood did not prolong graft survival. The suppression of the rejection reaction by whole blood transfusions, enhanced by non-specific immunosuppressive agents as observed in this study, has to be caused by other mechanisms. A search for these mechanisms has to be the subject of further investigation.

\section{Literature cited}

1. Opelz G., Terasaki P.I.: 1980 Transplantation 29: 153.

2. Persijn G.G., Cohen B., Lansbergen Q., et al: 1979 Transplantation 28: 396.

3. Stiller C.R., Sinclair N.R., Sheppard R.R., et al: 1978 Lancet 1: 169.

4. Rashid A., Sengar D.P.S.: 1978 Lancet 1: 825.

5. Hunsicker L.G., Oei L.S., Freeman R.M.: 1979 Transplant. Proc. 9: 156.

6. Persijn G.G., Van Hooff J.P., Kalff M.W., et al: 1977 Transplant. Proc. 9: 503.

7. Blamey R.W., Knapp M.S., Burden R.P., et al: 1978 Br Med J 1: 138.

8. Salaman J.R.: 1978 Lancet 1: 494.

9. Opelz G., Terasaki P.I.: 1979 N. Engl. d. Med. 299: 799.

10. Williams K.A., Ting A., French M.E., Oliver D., Morris P.J.: 1980 Lancet 1: 1104 .

11. Opelz G., Terasaki P.I.: 1981 Transplantation 31: 106.

12. Van Es A.A., Marquet R.L., Van Rood J.J., et al: 1978 Transplantation $26: 325$.

13. Fabre J.W., Bishop M., Sen T., et al 1978 Transplantation 26: 94.

14. Obertop H., Jeekel J., Vriesendorp H.M.: 1975 Transplantation 20: 49.

15. Obertop H., Bijnen A.B., Vriesendorp H.M., et al: 1978 Transplantation $26: 255$.

16. Bull R.W., Vriesendorp H.M., Obertop H., et al: 1978 Transplantation $26: 249$.

17. Keown P.A., Descamps B.: 1978 CR. Acad. Sc. Paris 287: 749.

18. Keown P.A., Descamps B.: 1979 Lancet 1: 20. 


\section{Publication 2}

Preoperative immunosuppression with antithymocyte serum and procarbazine: effect on kindney graft survival in dogs after donor or third party antigen administration

\section{Summary}

An overall positive effect of blood transfusions pre- or peroperatively on kidney graft survival has been established (1). However, the risk of sensitization of potential transplantation candidates is an important drawback for a liberal blood transfusion policy. By sensitization with blood transfusions, a certain group of patients is excluded from clinical transplantation.

Floersheim et al. described improved skin graft survival in rodents after preoperative treatment of the recipient with antithymocyte serum (ATS) and procarbazine. Preimmunization of the recipient with donor antigens in addition to pretreatment with antithymocyte serum and procarbazine improved graft survival time even more (2). Prolonged survival of canine renal allografts after donor and third-party transfusions in combination with ATS and procarbazine has been reported (3). In the present experimental model, preimmunization of the recipient also seemed to be essential. The clinical importance of ATS and procarbazine might be the application in sensitized patients as well as with transplantations in living-related combinations. In the latter group, deliberate antigen administration preoperatively could be considered. Transplantation in the dog seems to be an appropriate model for such studies, for a positive effect of blood transfusions on kidney graft survival as well as the risk of sensitization have been reported in dogs (4).

A summary of results obtained in related and nonrelated dogs that received a third-party or donor-specific transfusion in combination with ATS and procarbazine is reported.

Treatment with ATS and procarbazine in combination with third-party as well as donor-specific transfusions was successful in nonrelated dogs. However, we could not establish prolonged graft survivals in one haplotype mismatched beagles.

\section{Materials and methods}

Animals. Mongrel dogs and DLA-typed beagles were used.

Transplantation. Anesthesia consisted of fentanyl-base. Na-pentobarbital and $\mathrm{O}_{2} / \mathrm{N}_{2} \mathrm{O}$ gas. Left or right donor kidneys were transplanted to the right fossa iliaca of the recipient. Bilateral nephrectomy was performed at the end 
of the operation. The kidneys were flushed immediately after harvesting with $100-500 \mathrm{ml}$ cold Euro-Collins solution. The total ischemic time was always shorter than $45 \mathrm{~min}$. The end of graft survival was determined as the day that the serum creatinine rose above $1,000 \times 10^{-6}$ mole/liter or with the death of the recipient. Autopsy and histology were performed routinely.

Treatment of recipient. The immunosuppressive regimen lasted 6 days (from day -6 to -1 ) before transplantation on day 0 and consisted of procarbazine $12.5 \mathrm{mg} / \mathrm{kg}$ i.v. on days $-6,-4$, and -2 and ATS $0.6 \mathrm{ml} / \mathrm{kg}$ i.m. on days $-5,-3$, and -1 . Postoperative immunosuppression was not given. ATS was raised in New-Zealand white rabbits. Donor or third-party antigens were administered intravenously. The antigens used were $60 \mathrm{ml}$ blood or the plasma of that amount of blood. Liver was obtained by partial resection of the liver from the kidney donor. The liver was minced, washed, and kept frozen until use. Five-hundred milligrams wet weight/kg body weight of the sediment was injected.

\section{Results}

Kidney transplantation in nonrelated donor-recipient combinations without postoperative immunosuppression led to a mean survival time of 8 days (table 1).

In our experimental model, ATS and procarbazine pretreatment was not effective in nonsensitized recipients as we have reported before (3). Donorspecific blood transfused weekly for 5 weeks before transplantation followed. by our standard regimen of ATS and procarbazine increased mean graft survival to 17.6 days (table 1). A comparable prolongation of graft survival was found after donor-specific plasma injections and after donor-specific liver extract injections on days -18 and -11 combined with ATS and procarbazine (MST 16.6 days and 22.7 days, respectively). It seems, therefore, that ATS and procarbazine given on alternate days preoperatively increase graft survival if administered in combination with a variety of donor-specific antigens.

It also appeared that third-party plasma injection on days -18 , and -11 prolonged graft survival as well as donor-specific plasma (table 1).

The combination of donor-specific plasma and preoperative immunosuppression was also tested in related donor-recipient pairs. In one-haplotype mismatched, related donor-recipient combinations, a mean survival time of 23.8 days (table 2) was obtained. The survival time of one-haplotype mismatched related kidneys was not increased in a group of six beagles transplanted after donor-specific plasma injections on days -18 and -11 , followed by the standard ATS and procarbazine scheme (MST 22 days). 


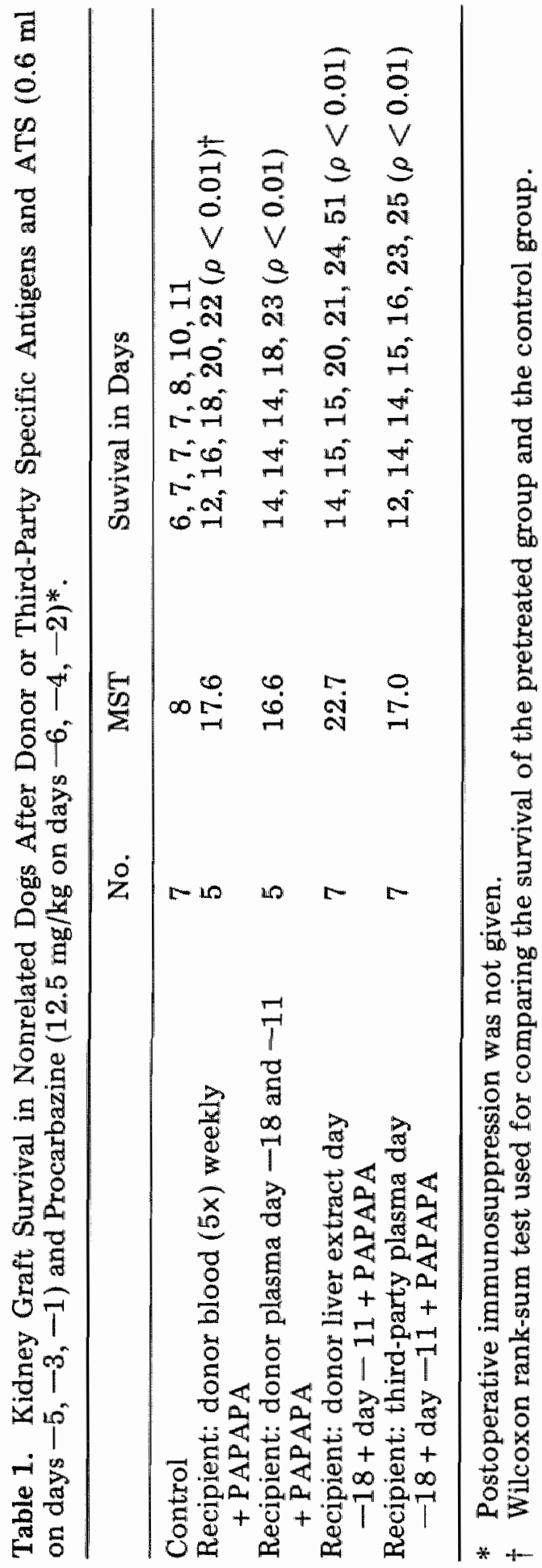


Table 2. Kidney Graft Survival in Related One-Haplotype Different Beagles After Donor-Specific Plasma and ATS $(0.6 \mathrm{ml}$ on day -5, -3, -1) and Procarbazine $(12.5 \mathrm{mg} / \mathrm{kg}$ on day $-6,-4,-2) *$.

\begin{tabular}{|c|c|c|c|}
\hline & No. & MST & Survival in Days \\
\hline Control & 10 & 23.8 & $\begin{array}{l}10,11,11,13,17, \\
20,31,39,42,44\end{array}$ \\
\hline $\begin{array}{l}\text { Recipient: donor plasma day } \\
-18 \text { and day }-11 \text { + PAPAPA }\end{array}$ & 6 & 22 & $\begin{array}{l}16,18,23,23,27 \\
31\end{array}$ \\
\hline
\end{tabular}

* Postoperative immunosuppression was not given.

\section{Discussion}

Procarbazine has been shown to be a potent immunosuppressive drug, especially in combination with ATS. This combination permits the use of lower dosages of ATS, which reduces the risk of toxic side effects (5). The synergistic effect of the two agents may be explained by a more specific effect of ATS on peripheral lymphocytes, whereas procarbazine works predominantly on lymphoid organs (6). Permanent tolerance of skin and fetal heart allografts in mice has been found after injection of donor antigens followed by procarbazine and ATS (2). The administration on alternate days of procarbazine and ATS has been demonstrated to be essential.

In nonrelated dogs we found increased graft survival after pretreatment with ATS and procarbazine in combination with donor antigen transfusions. Also, third-party antigen administration was effective in combination with ATS and procarbazine. These results are not in accordance with the concept that a specific immunologic mechanism is the cause of prolonged graft survival. Brent has suggested that donor-specific suppressor cells were reduced by combined treatment of donor antigen and immunosuppression. by ATS and procarbazine (6).

In our related dog model, we were unable to find increased graft survival after administration of donor plasma followed by ATS and procarbazine. The latter results are in contrast with results obtained by Brent (6) and our results with unrelated dogs. The administration of donor plasma from a related donor induces weak stimulation of the immune response, which might explain the disappointing results with related donor-recipient combinations. Our results might suggest that a strong stimulation of the immune apparatus of the recipient before transplantation is necessary to obtain improved graft survival with procarbazine and ATS. Thus, treatment with preimmunization and preoperative immunosuppression might be ineffective in related kidney transplantation in man according to our data. However, this protocol might be valuable in sensitized patients who are awaiting a cadaver kidney graft. Since the beneficial effect of procarbazine and ATS depends on the administration of donor or third-party antigens, it appears 
important to study the effect of blood transfusions in combinations with such immunosuppression.

\section{References}

1. Opelz G., Terasaki P.I.: Transplant. Proc. 9: 121, 1977.

2. Floersheim G.L.: Transplantation 15: 195, 1973.

3. Harder F., Floersheim G.L., Jeekel J., et al: Transplant. Proc. 11: 978, 1979.

4. Obertop H., Jeekel J., Vriesendorp H.M., et al: Transplantation 20: 49, 1975.

5. Floersheim G.L.: Lancet 2: 1386, 1973.

6. Brent L., Opara S.C.: Transplantation 27: 120, 1979. 


\section{Prolongation of canine renal allograft survival. A study on the effect of donor pretreatment}

\section{Summary}

Treatment of kidney donors with procarbazine hydrochloride and methylprednisolone, respectively, 5 and $2 \frac{1}{2} \mathrm{hr}$ before harvesting the kidney, improved renal allograft survival in dogs significantly. Pretreatment of the donor did not have a deleterious effect on the early function of the kidney grafts.

Donor blood transfused peroperatively into the recipient caused a significant reduction in survival of kidney grafts from pretreated donors, although it did not influence the survival of nontreated kidneys. Furthermore, it appeared that a peroperative injection of a suspension of nonirradiated donor lymphocytes as well as donor lymphocytes irradiated with 2,500 rad significantly decreased the survival time of pretreated kidneys. A peroperative transfusion of leukocyte-free blood prepared with a leukocyte filtration column, which leaves ery throcytes, thrombocytes, and plasma and eliminates most of the leukocytes $(99.9 \%)$, also abolished the effect of donor pretreatment.

Thus, administration of donor blood constituents, whether lymphocytes or leukocyte-free blood, can abrogate the beneficial effect of donor pretreatment on kidney graft survival. These data indicate that the effect of donor lymphocytes on the survival of pretreated kidneys is not because of a specific immunological activity of these lymphocytes but merely because of the presence of antigens on their cell surfaces.

\section{Introduction}

Guttmann et al. (1) reported in 1967 prolonged survival of rat allografts after pretreatment of the kidney donor with antithymocyte serum. Pretreatment of the donor with cyclophosphamide, methothrexate, or procarbazine hydrochloride led to comparable results (2). In the dog and in man, prolongation of graft survival after drug pretreatment of the kidney donor has also been demonstrated. Zincke et al. (3) obtained extension of graft survival in dogs after donor pretreatment with methylprednisolone, cyclophosphamide, and procarbazine hydrochloride or combinations of these drugs. The most promising data in these species were obtained with a com. bination of procarbazine hydrochloride and methylprednisolone (3). In man, 
donor pretreatment with cyclophosphamide and methylprednisolone has been reported to favour graft survival of unmatched cadaveric kidneys (4-7). However, the beneficial effect of donor pretreatment has been disputed recently by authors using the same drugs in comparable dosages. They report no significant difference in graft survival of pretreated and control kidneys (9-12). Furthermore, Burleson found histological evidence of tubular lesions in kidneys of dog donors pretreated with cyclophosphamide and methylprednisolone (8).

Different explanations have been given for the beneficial effect of donor pretreatment. It has been proposed that drug pretreatment causes a reduction in antigenicity of the graft. Furthermore, a reduced immune reaction of passenger leukocytes and also transplantation of drugs or drug metabolites with the graft have been suggested as being responsible for host immunosuppression (3, 13-15). The postulations that donor pretreatment can be either explained by a reduced graft antigenicity or a reduction of the immune reactivity of passenger leukocytes have been investigated in this study. During transplantation of pretreated kidneys, donor blood or donor blood components were transfused into the recipient. In our experiments donor pretreatment consisted of procarbazine hydrochloride and methylprednisollone.

\section{Materials and methods}

Animals. Male and female mongrel dogs varying in weight from 10 to 15 $\mathrm{kg}$ body wt were used.

Transplantation. Anesthesia consisted of fentanyl-base, Na-pentobarbital, and $\mathrm{O}_{2} / \mathrm{N}_{2} \mathrm{O}$ gas. Left or right donor kidneys were transplanted into the right iliac fossa. Bilateral nephrectomy was performed at the end of the operation. The kidneys were flushed immediately after harvesting with 100 to $500 \mathrm{ml}$ of cold Euro-Collins solution. The total ischemic time was always shorter than $45 \mathrm{~min}$. Postoperatively, all dogs received $2 \mathrm{mg}$ of azathioprine per $\mathrm{kg}$ body wt and $2 \mathrm{mg}$ of prednisone per $\mathrm{kg}$ body wt per day for the first 10 days, thereafter every other day. The end of graft survival was determined as the day that the serum creatinine rose above $1,000 \mathrm{x}$ $10^{-6}$ mole/liter or with the death of the recipient. Autopsy and histology were performed routinely.

Donor pretreatment. The pretreatment consisted of the administration of $50 \mathrm{mg}$ of i.v. procarbazine hydrochloride per $\mathrm{kg}$ body wt $5 \mathrm{hr}$ before and $50 \mathrm{mg}$ of i.v. methylprednisolone per $\mathrm{kg}$ body wt $2 \frac{\mathrm{l}}{2}$ hr before transplantation.

In vitro techniques. Naturally occurring antibodies of the recipient to the donor were tested using a one- and two-stage microcytotoxicity test. In none of the recipients were antibodies against the donor detected. Donor blood was drawn $5 \mathrm{hr}$ before transplantation just before donor pretreatment started. Fully heparinized donor blood was washed twice 
with saline and consisted of all blood components except plasma. Leukocyte-free donor blood was prepared by flushing $100 \mathrm{ml}$ of fresh citrated blood over a leukocyte filtration column (Red Cross Bloodtransfusion Service of The Netherlands). More than $99.9 . \%$ of the original leukocytes were removed using this method. The total amount of leukocyte decreased from an average of $7 \times 10^{6}$ cells $/ \mathrm{ml}$ to an average of 99 cells $/ \mathrm{ml}$. Leukocyte-free blood consisted of erythrocytes, $50 \pm 10 \%$ of the original thrombocytes and $50 \pm 15 \%$ of the original plasma protein. Lymphocytes were prepared by Ficoll-Isopaque density gradient centrifugation of $100 \mathrm{ml}$ of carbonyl iron-pretreated blood; $3.7 \times 10^{6}$ lymphocytes $/ \mathrm{kg}$ body wt were transfused. Irradiated lymphocytes received a dose of $2,500 \mathrm{rad}$, $250 \mathrm{kv}$ X-rays. All cell suspensions were immediately transfused to the recipient after transplantation had been finished.

\section{Results}

Transplantation of nonpretreated kidneys in bilaterally nephrectomized dogs (controls) led to a mean survival time of 7.7 days (group $\mathrm{A}$, table 1). Postoperative immunosuppression with azathioprine and prednisone increased graft survival to 12.6 days (group B). All further mentioned experimental groups received postoperative immunosuppression.

Donor pretreatment with procarbazine hydrochloride and methylprednisolone (group C) induced remarkably increased graft survival (mean survival time (MST) 26.8 days). The longest surviving pretreated graft was rejected at 55 days, 14 days after immunosuppression had been terminated. In the control group with immunosuppression graft survival was never longer than 21 days. Donor pretreatment had no obvious harmful effect on early kidney function, for creatinine levels in the 1st week postoperatively were similar to preoperative levels.

Donor blood was administered immediately after transplantation, to test whether or not the effect of donor pretreatment could be abolished by whole donor blood. A transfusion of $100 \mathrm{ml}$ of donor blood peroperatively itself did not influence graft survival (MST 12 days, group D). The graft survival time of kidneys from pretreated donors transplanted into recipients that received $100 \mathrm{ml}$ of whole donor blood (group E, table 2) peroperatively was not different from that of control data (group B). Whole donor blood administered peroperatively did abrogate the effect of donor drug pretreatment.

We investigated subsequently whether or not the disappearance of the donor pretreatment effect was attributable to the addition of donor antigens or to an immunological effect of the transfused donor lymphocytes. Transfusions of leukocyte-free blood containing donor antigens, present in plasma on erythrocytes and on thrombocytes, and transfusions of pure donor lymphocytes were administered immediately after a pretreated kidney had been transplanted. It appeared that a transfusion of $100 \mathrm{ml}$ of leukocyte-free 

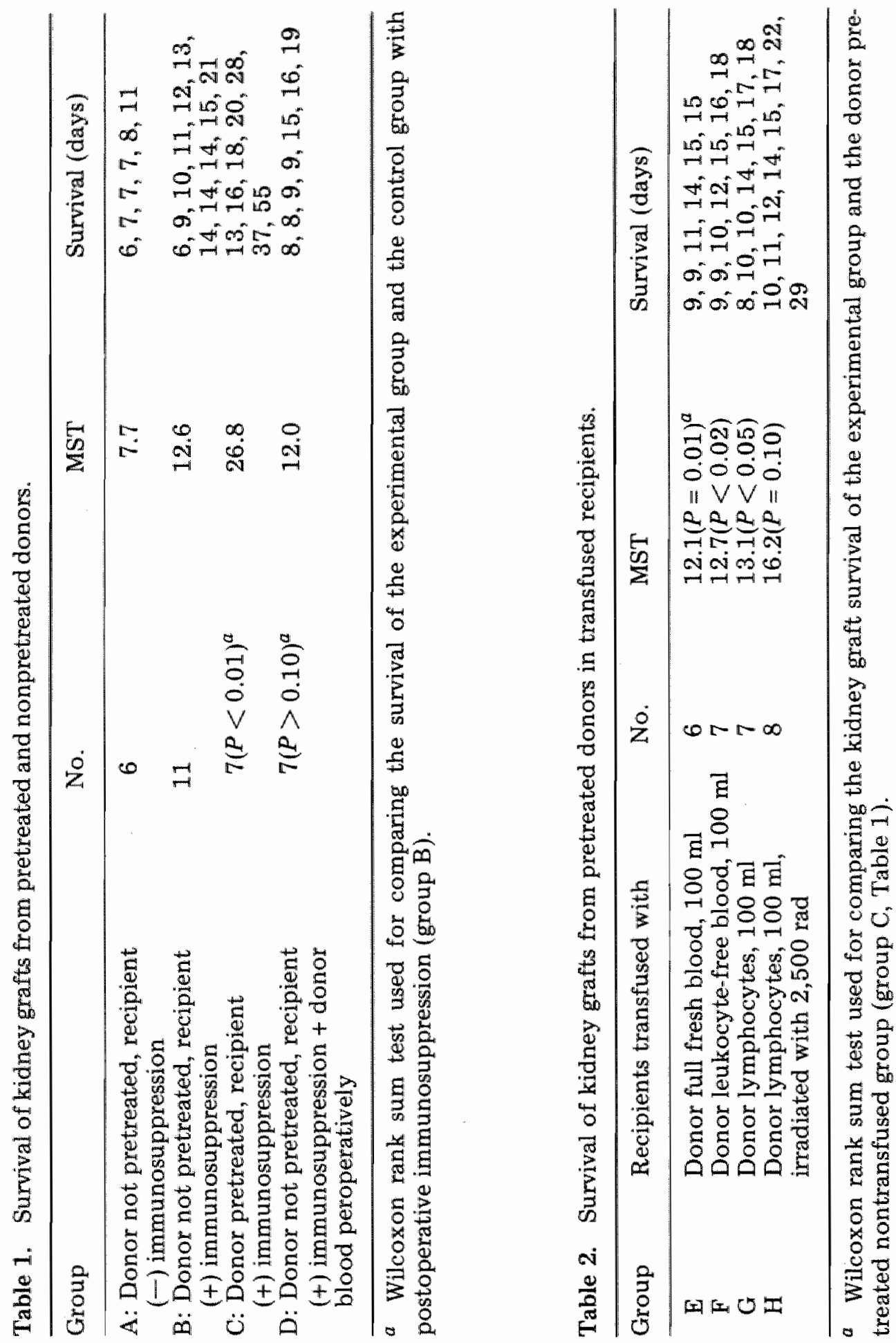
blood caused a decrease of graft survival of the pretreated kidney (MST 12.7 days, group F). The graft survival time was not significantly different from that of controls (group B). Moreover, a transfusion of lymphocytes obtained from $100 \mathrm{ml}$ of donor blood (group F) also led to loss of the beneficial effect of donor drug pretreatment (MST 13.1 days).

Irradiated donor lymphocytes have been transfused to test whether or not the decrease of survival time of pretreated kidneys induced by the peroperative administration of the lymphocytes could be ascribed to an immunological response of donor lymphocytes against host antigens or to donor antigens present on the cell surface of the lymphocytes. The survival time of pretreated kidney recipients receiving peroperatively irradiated donor lymphocytes (2,500 rad) of $100 \mathrm{ml}$ of blood (MST 16.2 days, group $\mathrm{H})$ did not differ significantly from that of control nontreated kidneys (group B). The data were different from the data of dogs that received nonirradiated lymphocytes (group G), but not at a significant level.

Our results indicate that the addition of donor antigens was essential in the reduction of graft survival time of pretreated kidneys.

\section{Discussion}

This study clearly shows that donor pretreatment with procarbazine hydrochloride and methylprednisolone can lead to significantly prolonged kidney graft survival in the dog.

It seems plausible that alteration of passenger leukocytes by donor pretreatment can explain the delayed rejection induced by donor pretreatment. Passenger leukocytes may be involved via two mechanisms: either the alloantigens on the passenger leukocytes stimulate the immune system of the recipient which initiate an immune response against these antigens, or passenger leukocytes react with the alloantigens present on the cell surface of the recipient resulting in a graft-versus-host reaction that may enhance graft rejection $(16,17)$.

Guttmann et al. (2) used alloantibodies to determine the density of major histocompatibility complex antigens on lymphocytes of rats pretreated with cyclophosphamide and methylprednisolone and found a reduction of lysis of target cells from pretreated rats by alloantiserum. It was concluded that the density of serologically defined major histocompatibility complex antigens on the surface of cells of pretreated donors was reduced. Furthermore, it has been shown that lymphocytes of pretreated donors have an impaired capacity to function as stimulator cells in a one-way mixed lymphocyte reaction (15). This suggests a reduced density of lymphocyte-defined antigens on such lymphocytes, which is in accordance with the earlier mentioned data that showed a reduced density of the serologically defined antigens on such lymphocytes of drug pretreated rats. It remained to be shown whether or not this related only to antigens on lymphocytes or also to antigens on cells of the kidney. 
As earlier shown and again confirmed in this study, a single donor blood transfusion does not influence kidney graft survival significantly (18). In the present experimental model, we studied the influence of a transfusion of donor antigens and donor lymphocytes on the survival of kidneys pretreated with procarbazine hydrochloride and methylprednisolone. The loss of the beneficial effect of donor pretreatment by a peroperative transfusion of 100 $\mathrm{ml}$ of donor blood in our experiments can be explained by the administration of donor antigenic material as well as by reactive donor lymphocytes. Because leukocyte-free blood, containing donor antigens in plasma, on erythrocytes, and on thrombocytes (cf. Materials and Methods), also reduced the graft survival time of pretreated grafts, the conclusion might be drawn that donor lymphocytes do not play an active role in reducing graft survival of pretreated kidneys. This was further supported by our finding that the administration of irradiated donor lymphocytes also seemed to abolish the effect of donor pretreatment, although to a lesser extent than nonirradiated donor lymphocytes. This might be ascribed to a longer presence of donor antigens when administered in the form of nonirradiated lymphocytes.

These data give suggestive evidence that donor antigens are capable of reducing graft survival in pretreated animals.

The hypothesis that drug metabolites transplanted along with the graft are responsible for the enhanced graft survival by systemic immune suppression, does not seem to be in accordance with experimental evidence which showed that peroperative administration of low amounts of immunosuppressive drugs has a negligible effect on graft survival (13). However, it is likely that small amounts of drugs are transplanted, since it is known that procarbazine hydrochloride reaches a maximum tissue level in dog kidney 30 to $60 \mathrm{~min}$ after i.v. injection and that $5 \%$ of the drug is excreted in the urine within the first $24 \mathrm{hr}(19)$. In dogs methylprednisolone has a half-time of 3.6 hr after i.v. injection and within the first $96 \mathrm{hr} 75 \%$ is excreted in the urine (20). Therefore, it has to be considered that a small amount of drugs is transplanted along with the graft. These drugs, then, may exert a local immune suppressive effect by inactivating stimulated host lymphocytes in the kidney.

Immune stimulation of host lymphocytes may occur by donor antigens administered i.v. peroperatively, resulting in a rejection reaction in spite of the local activity of drugs present in the kidney. This could explain the abrogation of prolonged graft survival of pretreated kidneys after transfusions of donor leukocyte-free blood and donor lymphocytes. The concept of a local immunosuppressive effect by drugs transplanted with the grafts is an alternative for the forementioned postulation that donor pretreatment decreases the antigenicity of the graft, as suggested by Guttmann (13). Both hypotheses are consistent with the data of this study. They form the objects of further study. 
1. Guttmann R.D., Carpenter C.B., Lindquist R.R., et al: 1967 J. Exp. Med. 126: 1099 .

2. Guttmann R.D., Lindquist R.R.: 1969 Transplantation 8: 490.

3. Zincke H., Woods J.E.: 1974 Transplantation 18: 480.

4. Guttmann R.D., Beaudoin J.G., Morehouse D.D.: 1973 Transplant. Proc. 5: 663 .

5. Guttmann R.D., Beaudoin J.G., Morehouse D.D., et al: 1975 Transplant. Proc. 7: 117 .

6. Zincke H., Woods J.E.: 1977 Surg. Gynecol. Obstet. 145: 183.

7. Zincke H., Woods J.E., Khan A.U., et al: 1978 Transplantation 26: 207.

8. Burleson R.L., Jones D.B., Yenikomshian A., et al: 1977 Transplant. Proc. 9: 1591.

9. Jeffery J.R., Downs A., Grahame J.W., et al: 1978 Transplantation 25: 287.

10. Chatterjee S.N., Terasaki P.I., Fine S., et al: 1977 Surg. Gynecol. Obstet. 145: 729 .

11. Barry J.M., Bennett W.M.: 1978 Transplantation 26: 202.

12. Soulillou J.P., Baron D., Rouvel A., et al: 1979 Nephron 24: 193.

13. Guttmann R.D.: 1974 Immunology 112: 1594.

14. Freeman J.S., Chamberlain E.C., Reemtsma K., et al: 1971 Transplant. Proc. 3: 580.

15. Jeffrey J.R., Guttmann R.D., Charpentier B.: 1976 Clin. Exp. Immunol. 25: 437 .

16. Elkins W.L.: 1968 Science 159: 1250.

17. Simonsen M., Buemann J., Gammeltoft A., et al: 1953 Acta Pathol. Microbiol. Scand. 32: 1.

18. Jeekel J., Obertop H., Vriesendorp H.M., et al: 1975 Transplant. Proc. 3: 435 .

19. Schwartz D.E., Bollag W., Obrecht P.: 1967 Arzneim. Forsch. 17: 1389.

20. Rosenburg J.C., Colburn W.A., Brennan P., et al: 1975 Transplant. Proc. 7: 547 . 


\section{A study on the mechanism of donor pretreatment. Effect of procarbazine hydrochloride and methylprednisolone on immunocompetent cells}

\section{Summary}

Significantly prolonged canine renal allograft survival can be obtained by donor pretreatment with procarbazine hydrochloride and methylprednisolone. This is thought to be caused either by a reduced antigenicity of the graft or by a local immunosuppressive effect by drugs transplanted with the graft.

In this study a decrease in the number of peripheral donor $\mathrm{T}$ and $\mathrm{B}$ lymphocytes was observed at the time of procuring. Leukocytes harvested from dogs pretreated with a combination of procarbazine hydrochloride and methylprednisolone showed a decrease in their ability either to stimulate or respond in mixed leukocyte cultures (MLCs). Complete restoration of MLC responses was obtained however by purification and washing of these leukocytes. Sera of pretreated animals were not able to reduce MLC responses. It was concluded that drug metabolites in or on the cells were apparently responsible. A local inhibition of the immunocompetence of host lymphocytes by small amounts of transplanted drug metabolites in or on the graft cells might be responsible for the beneficial effect of donor pretreatment with procarbazine hydrochloride and methylprednisolone. Furthermore, this postulation explains the abrogation of prolonged survival of pretreated grafts after systemic administration of nontreated donor blood or donor leukocyte-free blood, as we reported earlier.

\section{Introduction}

Donor drug pretreatment prolongs renal allograft survival in experimental animals $(1.5)$. However, the effect of pretreatment of human cadaveric donors in renal transplantation is a matter for debate (6-13). The assumption throughout has been that donor drug pretreatment leads to a reduction of the number of passenger leukocytes which diminishes the immunogenicity of the graft leading to prolonged graft survival.

In 1974 Guttmann (14) reported a reduced responsiveness and stimulation ability of rat lymphocytes in MLC and phytohemagglutinin stimulation after pretreatment with $250 \mathrm{mg}$ of cyclophosphamide per $\mathrm{kg}$ i.p. In man, similar findings have been reported for lymphocytes obtained $4 \mathrm{hr}$ after donor pretreatment with $5 \mathrm{~g}$ of cyclophosphamide and $5 \mathrm{~g}$ of methylpredni- 
solone (15). Recently, Oluwole et al. (16) observed that the number of passenger leukocytes was not reduced in rat heart allografts after i.p. administration of $200 \mathrm{mg}$ of cyclophosphamide per $\mathrm{kg}$. They stressed the possibility that cyclophosphamide might be effective by altering cells of the graft to the extent that they become less effective immunogens.

Impressive prolongation of allograft survival has also been obtained by donor drug pretreatment with procarbazine hydrochloride and methylprednisolone. In rat and $\mathrm{dog}$, this combination is as effective as cyclophosphamide and methylprednisolone $(1,3,4)$. We reported a significantly prolonged kidney graft survival of 26.8 days after donor pretreatment with procarbazine hydrochloride and methylprednisolone, whereas the control dogs survived for 12.6 days (17). The effect of procarbazine hydrochloride with methylprednisolone on immunocompetent cells is largerly unknown.

In this study, the effect of procarbazine hydrochloride and methylprednisolone on the number of white blood cells and on the function of leukocytes in a one-way MLC has been investigated. Peripheral leukocytes have been used since these cells are readily accessible. It is likely that altered responses of these cells in MLC reflect the influence of this combination of drugs on graft cells and circulating host immunocompetent cells within the graft.

Depressed function of leukocytes after procarbazine hydrochloride and methylprednisolone administration was found in a one-way MLC. This depression was not observed after purification and washing of these leukocytes. This phenomenon has not been described earlier. Its relevance for a prolongation of allograft survival after donor drug pretreatment with procarbazine hydrochloride and methylprednisolone is discussed.

\section{Materials and methods}

Animals. Male and female beagles of 3 months of age were commercially obtained from the colony of the Centraal Proefdierenverblijf TNO, Austerlitz, The Netherlands. These animals were used for drug treatment. Bouviers de Flanders of the colony of the State University of Limburg were selected for a strong $\mathrm{MLC}$ responsiveness towards the relevant beagles (stimulation index $>10$ ). Leukocytes of these selected dogs have been used as responder and stimulator cells in MLC, respectively, with stimulator and responder cells of the pretreated beagles.

Drug pretreatment. Pretreatment consisted of the administration of $50 \mathrm{mg}$ of procarbazine hydrochloride per kg body wt i.v. (Natulan: generous gift from Roche, Basel, Switzerland), and $50 \mathrm{mg}$ of methylprednisolone per $\mathrm{kg}$ body wt i.v. (Solu-Medrol: generous gift from Upjohn, Ede, The Netherlands), respectively, at 0 and $2 \frac{1}{2} \mathrm{hr}$. This schedule is a highly effective donor drug pretreatment schedule in dogs if procuring, and transplantation would occur after $5 \mathrm{hr}$.

Blood samples. Blood was drawn at $0 \mathrm{hr}(\mathrm{O}$ hr sample) just before procarbazine hydrochloride administration, at $2 \frac{1}{2} \mathrm{hr}$ just before methylpredni- 
solone administration ( $2 \frac{1}{2}-\mathrm{hr}$ sample), and at $5 \mathrm{hr}$ ( 5 -hr sample).

Cell suspensions. Leukocytes were prepared immediately after blood drawing by Ficoll-metrizoate (Lymphoprep; Nyegaard, Oslo, Norway), $\delta=$ $1.077 \mathrm{~g} / \mathrm{cm}^{3}$, density centrifugation and thereafter washed with RPMI medium (= purified, washed leukocytes). Leukocytes were also prepared by harvesting white cell buffy coat of centrifuged blood $(1,000 \mathrm{~g}$ at 22 to $25 \mathrm{C}$ for $20 \mathrm{~min}$ ) (= buffy coat leukocytes).

$M L C$. Stimulator cells A $\left(1.5 \times 10^{5}\right.$, irradiated with $\left.2,500 \mathrm{rad}\right)$ were cultured with $1.5 \times 10^{5}$ responder cells B in RPMI 1640 plus $25 \mathrm{mM}$ HEPES (Grand Island Biological Co., Europe) plus $2 \mathrm{mM}$ glutamine plus $10 \%$ inactivated pooled canine serum, containing 100 units of penicillin and $100 \mu \mathrm{g}$ of streptomycin $/ \mathrm{ml}$ for 5 days at $37 \mathrm{C}$. Cultures were set up in 6-fold in microtiter plates. Buffy coat lymphocyte cultures contained $0.4 \mu \mathrm{l}$ of the original serum of the pretreated animal. After 5 days $1 \mu \mathrm{c}$ of $\left({ }^{3} \mathrm{H}\right.$ ) TdR (Amersham, United Kingdom) was added, the cultures were harvested $4 \mathrm{hr}$ later on glass fiber filters and the ${ }^{3} \mathrm{H}$ uptake was counted in a liquid scintillation counter and expressed as cpm. Stimulation indices have been calculated:

stimulation index $=\frac{\text { cpm experimental } A B_{x}}{\text { cpm control } \mathrm{AA}_{\mathrm{x}}}$

In those MLCs where the effect of the serum of pretreated dogs on nontreated leukocytes was tested, the nontreated inactivated pooled canine serum of the culture medium was partially replaced by pretreated serum.

Immunofluorescence. Defibrinated blood was subjected to cell separation with Lymphoprep. To free cells of receptorbound Ig, cells were incubated for $45 \mathrm{~min}$ at $37 \mathrm{C}$ in serum-free Hanks balanced salt solution plus $1.0 \%$ bovine serum albumin plus $0.01 \% \mathrm{NaNH}_{3}$ and incubated for $30 \mathrm{~min}$ with tetramethylrhodamine isothiocyanate-conjugated rabbit $\operatorname{IgG} F\left(a b^{\prime}\right)_{2}$ antidog IgG (heavy and light chains) obtained from URSB (Cleveland, Ohio). Cells were washed twice after staining with phosphate-buffered saline plus $1.0 \%$ bovine serum albumin plus $0.01 \% \mathrm{NaN}_{3}$ suspended in glycerol-phosphate buffered saline and mounted for microscopy. A Leitz Dialux 20 microscope was used.

\section{Results}

Peripheral blood cell counts after drug administration. The influence of procarbazine hydrochloride and methylprednisolone on the number of peripheral leukocytes after i.v. injection is depicted in table 1. A significant decrease of the number of lymphocytes from $36 \%\left(4.9 \times 10^{6} \mathrm{cell} / \mathrm{ml}\right)$ to $14 \%\left(2.8 \times 10^{6} \mathrm{cell} / \mathrm{ml}\right)$ was found in the $5-\mathrm{hr}$ sample. The total number of white cells per milliliter of blood increased from $13.7 \times 10^{6}$ cells to $20.3 \times$ $10^{6}$ cells because of an increase in the number of neutrophils $\left(8.1 \times 10^{6}\right.$ to $16.8 \times 10^{6}$ cells $\left./ \mathrm{ml}\right)$. The percentage of $\mathrm{sIg}^{+}$cells of the lymphocyte fraction 


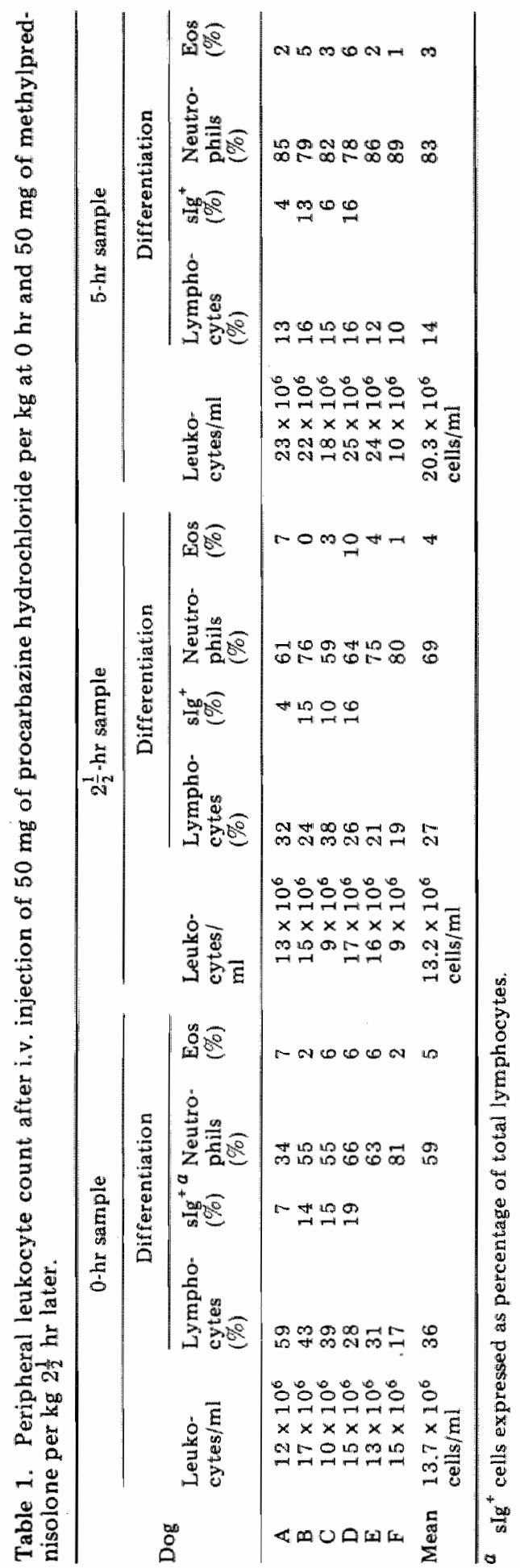


remained unaltered, which indicates that there was no specific depletion of $\mathrm{T}$ or B cells.

MLC responsiveness and stimulation capacity of buffy coat leukocytes after drug administration. The effect of procarbazine hydrochloride and methylprednisolone on the immunocompetence of leukocytes was tested in MLC. Figures 1 and 2 show the ${ }^{3} \mathrm{H}$-thymidine uptake in $\mathrm{cpm}$ of buffy coat leukocytes (responder or stimulator cells) from 16 drug-treated animals, respectively, before drug administration, $2 \frac{1}{2} \mathrm{hr}$ after $50 \mathrm{mg}$ of procarbazine hydrochloride per $\mathrm{kg}$, and 5 and $2 \frac{1}{2} \mathrm{hr}$ after the administration of $50 \mathrm{mg}$ of procarbazine hydrochloride per $\mathrm{kg}$ and $50 \mathrm{mg}$ of methylprednisolone per $\mathrm{kg}$, respectively.

Stimulation indices of MLC with drug-treated stimulator cells $(p=0.011)$ as well as of MLC with drug-treated responder cells $(p=0.052)$ are significantly depressed in the 5-hr sample*.

* Significance has been tested with the sign test (18).

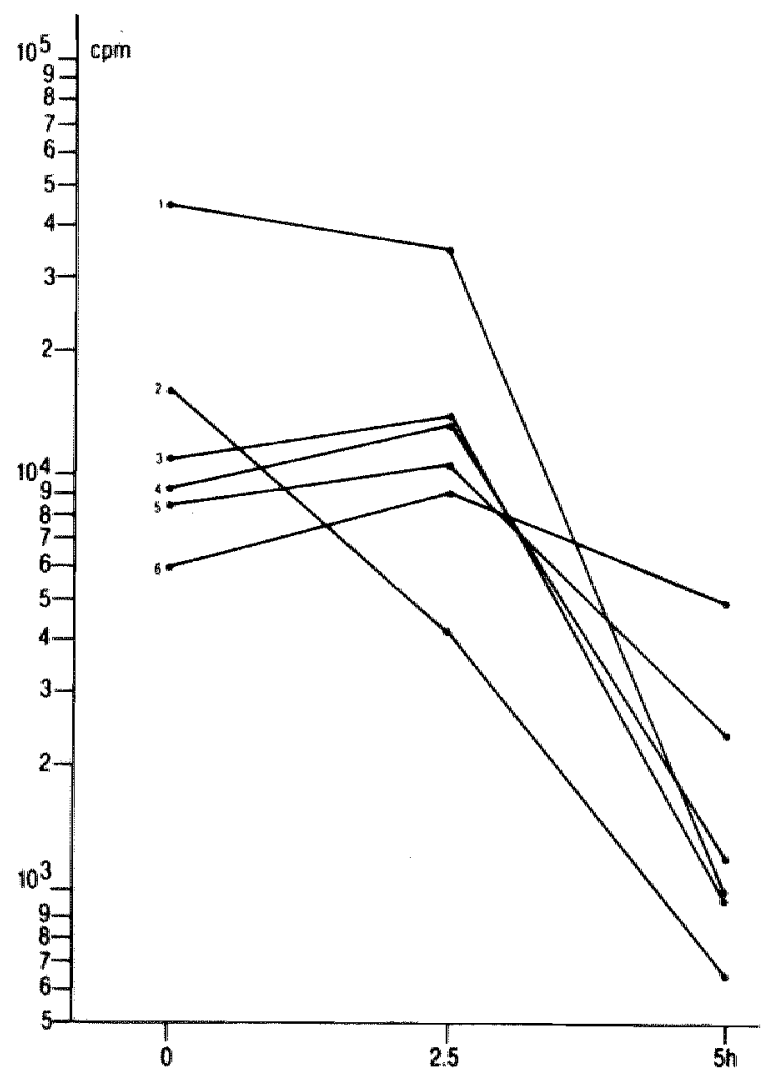

Fig. 1 Influence of $50 \mathrm{mg}$ of procarbazine hydrochloride $(0 \mathrm{hr})$ per $\mathrm{kg}$ and $50 \mathrm{mg}$ of methylprednisolone $\left(2 \frac{1}{2} \mathrm{hr}\right)$ per kg administration on MLC responsiveness of buffy coat leukocytes at $0,2 \frac{1}{2}$, and $5 \mathrm{hr}$. 
MLC responsiveness and stimulation capacity of purified washed leukocytes after drug administration. To reveal the influence of contamination by drugs in serum of pretreated animals or drug adherence to cells present in the cultures of buffy coat leukzocytes, two additional sets of experiments were performed. Leukocytes suspensions of pretreated animals were made by Lymphoprep density centrifugation and thereafter carefully washed with RPMI medium to remove the $0.4 \mu \mathrm{l}$ serum of the pretreated animals present in cultures of buffy coat lymphocytes. These purified washed leukocytes showed an unaltered good stimulation and responsiveness in MLC before and after drug administration (figs. 3 and 4). This effect of density centrifugation and washing cannot be attributed to a selective depletion of specific types of leukocytes, since this procedure does not lead to a change in the ratio of the different leukocytes present in canine blood (Buurman et al., to be submitted). This convincingly rules out the possibility of a decreased immunogenicity of the cells after pretreatment and strongly favours the hypothesis of a direct drug-mediated mechanism leading to depressed MLC responses in buffy coat cell suspensions.

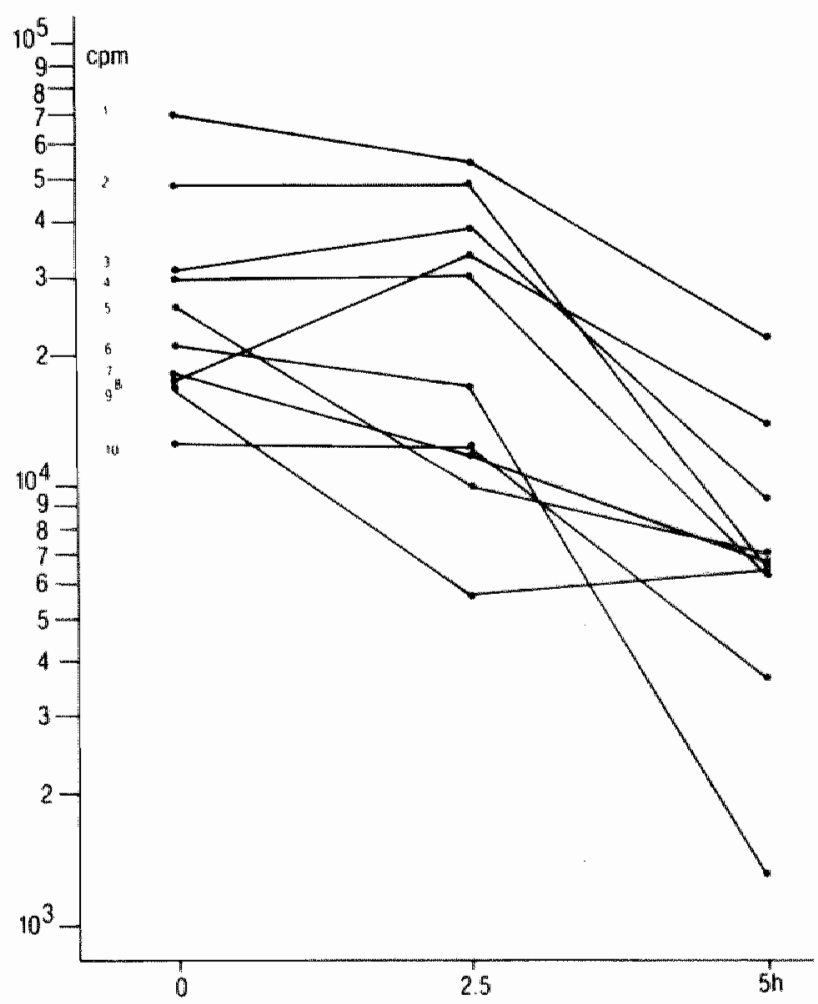

Fig. 2 Influence of $50 \mathrm{mg}$ of procarbazine hydrochloride $(0 \mathrm{hr})$ per $\mathrm{kg}$ and $50 \mathrm{mg}$ of methylprednisolone $\left(2 \frac{1}{2} \mathrm{hr}\right)$ per $\mathrm{kg}$ administration on MLC stimulation capacity of buffy coat leukocytes at $0,2 \frac{1}{2}$, and $5 \mathrm{hr}$. 


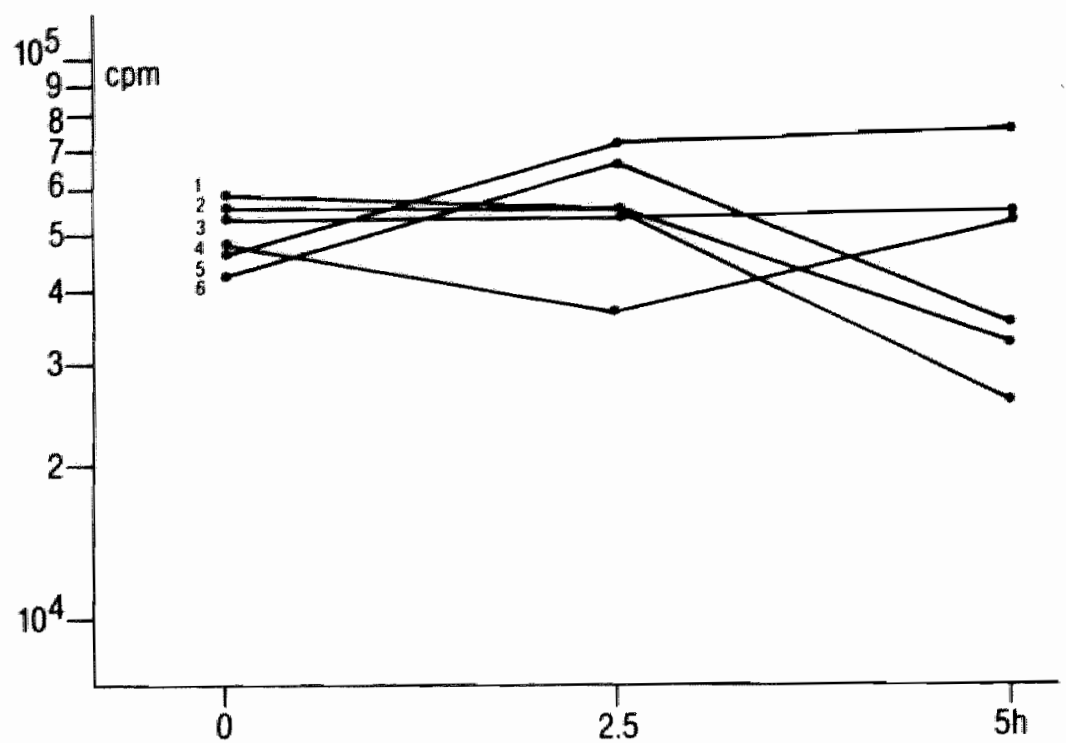

Fig. 3 Influence of $50 \mathrm{mg}$ of procarbazine hydrochloride $(0 \mathrm{hr})$ per $\mathrm{kg}$ and $50 \mathrm{mg}$ of methylprednisolone $\left(2 \frac{1}{2} \mathrm{hr}\right)$ per $\mathrm{kg}$ administration on MLC responsiveness of purified, washed leukocytes at $0,2 \frac{1}{2}$, and $5 \mathrm{hr}$.

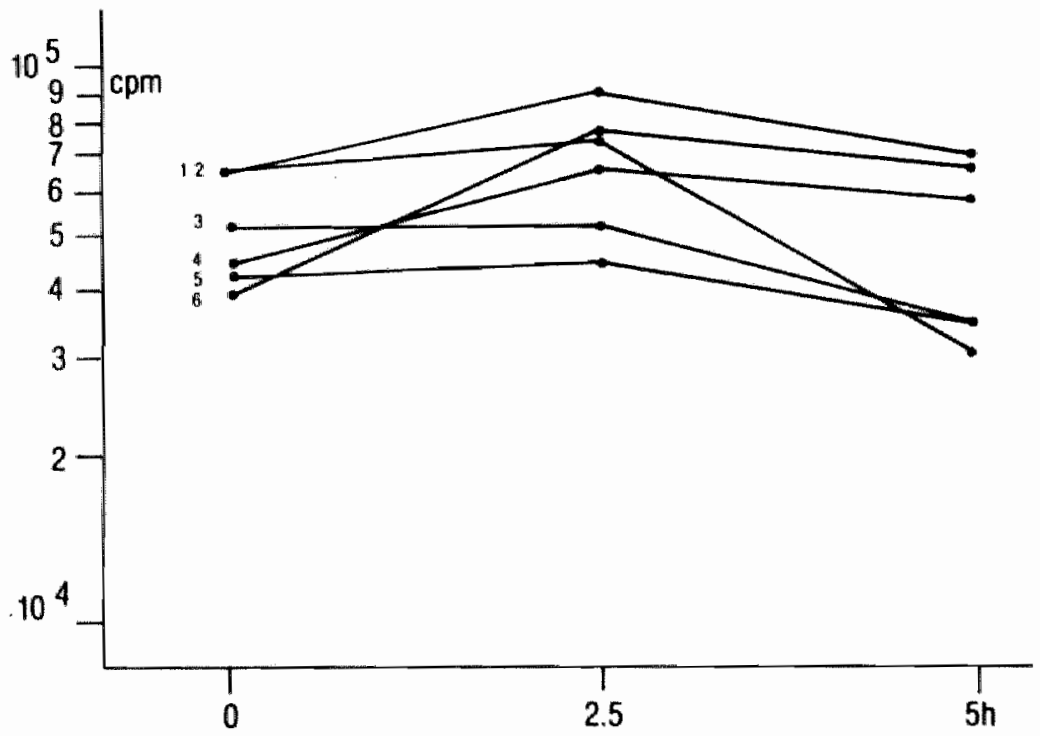

Fig. 4 Influence of $50 \mathrm{mg}$ of procarbazine hydrochloride $(0 \mathrm{hr})$ per $\mathrm{kg}$ and $50 \mathrm{mg}$ of methylprednisolone ( $2 \frac{1}{2} \mathrm{hr}$ ) per $\mathrm{kg}$ administration on MLC stimulation capacity of purified, washed leukocytes at $0,2 \frac{1}{2}$, and $5 \mathrm{hr}$. 


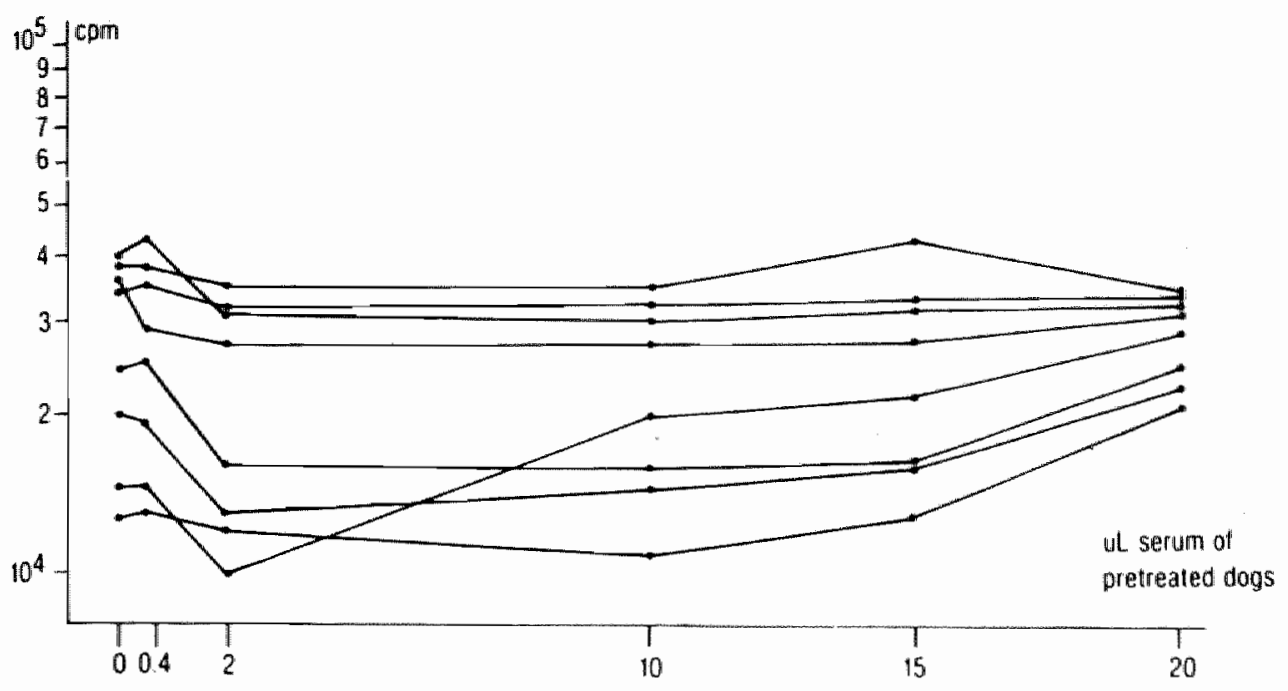

Fig. 5 Influence of increasing amounts of serum of pretreated dogs added to MLC of nontreated leukocytes.

MLC responsiveness and stimulation capacity of leukocytes after addition of serum of pretreated animals. Sera of dogs obtained $5 \mathrm{hr}$ after drug administration were added to MLC cultures of nontreated leukocytes. An increasing amount was added ( 0.4 to $20 \mu \mathrm{l})$. As shown in figure 5 , no influence on MLC responses could be found by the addition of pretreated serum. This indicates that sera of pretreated animals do not contain active drug metabolites in sufficient amounts to suppress MLC responses.

\section{Discussion}

The experience with procarbazine hydrochloride, a methylhydrazine derivative, in donor drug pretreatment has been restricted in man to only a few patients (19). In experimental animals its efficacy has been established and has been proven to be as good as cyclophosphamide $(1,3,4,17)$. Prolonged survival after donor drug pretreatment with the latter drug has been suggested as being attributable to a reduced immunogenicity of passenger leukocytes or other cells of the graft (16-20). This is in accordance with the abservation that cyclophosphamide and its most active compounds, 4hydroperoxycyclophosphamide and phosphoramide mustard, are capable of inhibiting the regeneration of sIg receptors on B cells (21).

In this study, the effect of procarbazine hydrochloride and methylprednisolone on circulating white blood cells has been investigated. Pretreatment with this combination of drugs caused a significant lymphopenia. Whether or not this indicates that there is a decrease of passenger leukocytes remains unsure. However, it is known that cyclophosphamide pretreatment causes 
severe lymphopenia without a reduction of passenger leukocytes (16). The total number of circulating leukocytes did not decrease. A depression of responsiveness and stimulation capacity of leukocytes from pretreated animals was found in MLC which could be completely reversed by purification and washing of these cells. This observation could not be attributable to the presence of drugs in serum of pretreated dogs in culture with buffy coat leukocytes, since the addition of larger amounts of serum from the pretreated dogs to nontreated leukocyte suspensions did not influence MLC responses. The depression of MLC responses of buffy coat leukocytes is, in our opinion, most likely attributable to drug metabohtes in or on cells, which are removed by purification and washing. The short, $12 \mathrm{~min}$, serum half time of procarbazine hydrochloride in dogs effectively explains that relatively high amounts of serum of pretreated dogs obtained $5 \mathrm{hr}$ after procarbazine hydrochloride administration did not suppress MLC responses (22).

In an earlier study, we reported that a peroperatively given transfusion of nontreated whole donor blood or nontreated leukocyte-free donor blood abrogates the prollongation of renal allograft survival induced by procarbazine hydrochloride and methylprednisolone (17). Based on these earlier reported findings and the data of this study, we suggest that prolongation of renal allograft survival after procarbazine hydrochloride and methylprednisolone administration is attributable to a small amount of drugs in or on graft cells that are transplanted along with the graft. These transplanted drugs may inhibit the response of host lymhocytes possibly by a transfer of drugs during the close contact with the grafted cells, necessary for initiating the response of the lymphocytes. Furthermore, the drugs may inhibit the immune response of passenger leukocytes.

The immune system of the host in general will not be influenced by small amounts of transplanted drugs. This explains the normal survival of pretreated grafts that we found after systemical administration of donor antigens into the recipient, since these antigens lead to immunization of the host (17). The explanation for the effect of donor pretreatment with procarbazine hydrochloride and methylprednisolone that drugs are transplanted in or on the graft is in contrast with the assumption of reduced immunogenicity by which donor pretreatment with cyclophosmphamide is thought to be effective (23).

\section{Literature cited}

1. Guttmann R.D., Lindquist R.R.: 1969 Transplantation 8: 490.

2. Freeman J.S., Chamberlain E.C., Reemtsma K., et al: 1971 Transplant. Proc. 3: 580 .

3. Zincke H., Woods J.E.: 1974 Transplantation 18: 480.

4. Soots A., Häyry P.: 1978 Transplantation 25: 259.

5. Swistel A.J., McGabe R.E., Lorieo D.R., et al: 1979 Transplant. Proc. $11: 1673$. 
6. Guttmann R.D., Beaudoin J.G., Morehouse D.D.: 1973 Transplant. Proc. 5: 663 .

7. Guttmann R.D., Beaudoin J.G., Morehouse D.D., et al: 1975 Transplant. Proc. $7: 117$.

8. Zincke H., Woods J.E., Khan A.U., et al: 1978 Transplantation 26: 207.

9. Zincke H., Woods J.E.: 1977 Surg. Gynecol. Obstet. 145: 183.

10. Jeffery J.R., Downs A., Grahame J.W., et al: 1978 Transplantation 25: 287.

11. Barry J.M., Bennett W.M.: 1978 Transplantation 26: 202.

12. Soulillou J.P., Baron D., Rouxel A., et al: 1979 Nephron. 24: 193.

13. Chatterjee S.N., Terasaki P.I., Fine S., et al: 1977 Surg. Gynecol. Obstet. 145: 729 .

14. Guttmann R.D.: 1974 Immunology 112: 1594.

15. Jeffery J.R., Guttmann R.D., Charpentier B.: 1976 Clin. Exp. Immunol. 25: 437 .

16. Oluwole S., Hardy M.A., Wang T., et al: 1980 Transplantation 30: 31 .

17. Van der Linden C.J., Buurman W.A., Vegt P.A., et al: 1980 Transplantation 30: 132 .

18. Sarris V., Wilkening F.: 1977 Biometrical J. 19: 339.

19. Zincke H., Woods J.E., Roses J., et al: 1976 Mayo Clin. Proc. 51: 693.

20. Nowygrod R., Hardy M.A., Todd G.J., et al: 1979 Transplant. Proc. 11: 1462 .

21. Shand F.L., Howard J.G.: 1979 Eur. J. Immunol. 9: 17.

22. Schwartz D.E., Bollag W., Obrecht P.: 1967 Arzneim. Forsch. 17: 1389.

23. Waltzer W.C., Zincke H., Sterioff S., et al: 1980 Transplantation 29: 249. 
The effect of transfusions and donor pretreatment on canine renal allograft survival

\section{Summary}

Allograft survival is influenced by a complexity of known and unknown factors. The effect of several types of transfusion on renal allograft survival has been studied in mongrel dogs. Nontreated and drug-pretreated kidneys were transplanted. Preoperative and peroperative cell suspensions of unrelated dogs were transfused to graft recipients. All recipients received lowdose postoperative immunosuppression. One peroperative transfusion of 100 $\mathrm{ml}$ third-party blood enhanced graft survival of nontreated kidneys significantly. A transfusion of $100 \mathrm{ml}$ blood 14 days before transplantation led to variable results, whereas a transfusion of cells obtained from a third-party splleen, given 14 days before transplantation, did not prolong graft survival of nontreated kidneys at all. The administration of procarbazine hydrochloride and methylprednisolone to the donor before procuring the graft increased survival of canine renal allografts significantly. A combination of donor drug pretreatment and $100 \mathrm{ml}$ peroperative third-party blood led to graft survival comparable to that obtained by either treatment. Pretreatment of the recipient with spleen cells 14 days before transplantation even abrogated the effect of donor drug pretreatment completely. These results show that preoperative transfusions cannot successfully be combined with donor drug pretreatment as commonly practiced in man. This is a possible explanation for the conflicting data on donor pretreatment in man. Furthermore this study gives evidence for the effectiveness of a peroperative blood transfusion on kidney graft survival.

\section{Introduction}

A beneficial effect of preoperative blood transfusions on kidney graft survival has been shown in man by Opelz and co-workers (12). Recent controlled animal studies confirm this finding $(1,3,5,6,11)$. Although the beneficial effect of preoperative blood transfusions is now generally accepted, the optimal transfusion schedule is still questionable. Only some evidence exists that a peroperative blood transfusion can also improve graft survival in man (13). This schedule bears the advantage of a lower risk of sensitization of the recipient compared to a multiple preoperative blood transfusion schedule. 
Strong experimental evidence has been published during the last decennium that suggests that donor drug pretreatment effectively prolongs kidney graft survival in animals $(7,10,14)$, but in contrast, clinical reports on donor drug pretreatment are highly controversial $(2,4,8,9,15)$. The above-mentioned discrepancy of effectiveness of donor drug pretreatment might be attributed to the fact that in clinical settings, donor drug pretreatment is almost unvariably combined with other treatment schedules which influence graft survival. We suggest the possibility that combinations of treatments do not improve or even impair results obtained by one treatment.

We tested the effect of different transfusions on the survival of drug pretreated and nonpretreated kidneys in a canine model. A beneficial effect of one peroperative blood transfusion was found but an additional improvement of graft survival after blood transfusions by donor pretreatment could not be established.

\section{Materials and methods}

Animals. Male and female mongrel dogs varying in weight from 10 to 25 $\mathrm{kg}$ body wt were used.

Transplantation. Anesthesia consisted of fentanyl base, sodium pentobarbitol, and $\mathrm{O}_{2} / \mathrm{N}_{2} \mathrm{O}$ gas. Left or right donor kidneys were transplanted to the right fossa iliaca of the recipient. Bilateral recipient nephrectomy was performed at the end of the operation. The kidneys were flushed immediately after harvesting with $100-500 \mathrm{ml}$ cold Euro-Collins solution. The total ischemic time was always shorter than $45 \mathrm{~min}$.

Immunosuppression. For postoperative immunosuppression all dogs received $2 \mathrm{mg} / \mathrm{kg}$ azathioprine and $2 \mathrm{mg} / \mathrm{kg}$ prednisone every day for the first 10 days, thereafter every other day.

Kidney graft survival. The end of graft survival was determined as the day that the serum creatinine raised above $1,000 \times 10^{-6}$ mole/liter or with the death of the recipient. Autopsy and histology were performed routinely.

Donor drug pretreatment. Pretreatment consisted of the administration of $50 \mathrm{mg} / \mathrm{kg}$ body wt procarbazine hydrochloride i.v. and $50 \mathrm{mg} / \mathrm{kg}$ body wt methylprednisolone i.v., respectively, 5 and $2 \frac{1}{2}$ hr prior to transplantation.

Recipient third-party blood cell pretreatment. Heparinized third-party blood $(100 \mathrm{ml})$ was washed twice with saline and consisted of all blood constituents except plasma. Peroperatively third-party blood transfusions were given after arterial and venous anastomoses were finished. The transfused amount of blood cells averaged $4 \times 10^{10}$ cells $/ \mathrm{kg}$ body wt. Spleen cell suspensions were prepared from third-party spleens obtained by splenectomy of living donors. Suspensions were immediately made by mincing spleens through sieves until a single-cell suspension, dissolved in saline, was obtained. Spleen cell transfusions to the recipient were given on the day of splenectomy. The amount of transfused cells obtained from these spleens averaged 
$6.5 \times 10^{10}$ cells $/ \mathrm{kg}$ body wt. The average viability of these cells was higher than $90 \%$.

\section{Results}

Nontreated kidneys in bilaterally nephrectomized dogs had a mean survival of 12.6 days (group A, table 1 ). The interval between blood transfusion and transplantation appeared to be important since a transfusion of $100 \mathrm{ml}$ third-party blood peroperatively led to significant prolongation (MST 21.0 days, group B, table 1), whereas a transfusion of $100 \mathrm{ml}$ third-party blood 14 days before transplantation led to less enhanced and more variable graft survival (MST 18.5 days, group $\mathrm{C}$, table 1 ). The amount and composition of the cells also played a role. A transfusion of twice as much cells obtained from a third-party spleen administered 14 days before transplantation induced no prolongation at all (MST 10.3 days, group A, table 2). Even a slight decrease in survival could be noted in this last group, although donorrecipient cross-match at the time of operation was negative for all dogs.

The effect of donor drug pretreatment on graft survival appeared to

Table 1. The effect of third-party blood transfusion on kidney graft survival of pretreated and nonpretreated kidneys in mongrel dogs.

\begin{tabular}{|c|c|c|c|c|c|c|}
\hline Group & $\begin{array}{l}\text { Drug } \\
\text { pretreatment } \\
\text { (donor) }\end{array}$ & $\begin{array}{l}\text { Peroperative } \\
\text { blood } \\
\text { transfusion } \\
\text { (recipient) }\end{array}$ & No. & $\mathrm{MST}$ & Survival (days) & $P$ \\
\hline $\mathrm{A}$ & \multirow[t]{3}{*}{ Nonpretreated } & Nontransfused & $\mathbb{1 1}$ & 12.6 & $\begin{array}{l}6,9,10,11,12, \\
13,14,14,14 \\
15,21\end{array}$ & \\
\hline B & & $\begin{array}{l}\text { Transfused, } \\
100 \mathrm{ml} \text { blood } \\
\text { peroperatively }\end{array}$ & 12 & 21.0 & $\begin{array}{l}14,15,15,16 \\
20,20,20,24 \\
25,25,29,29\end{array}$ & $<0.01 *$ \\
\hline $\mathrm{C}$ & & $\begin{array}{l}\text { Transfused, } \\
100 \mathrm{ml} \text { blood } \\
\text { on Day - } 14\end{array}$ & 8 & 18.5 & $\begin{array}{l}11,11,13,14 \\
17,21,23,38\end{array}$ & $\mathrm{n}_{\mathrm{s}} \mathrm{s}_{*}$ * \\
\hline $\mathrm{D}$ & \multirow[t]{2}{*}{ Pretreated } & Nontransfused & 7 & 26.8 & \multirow{2}{*}{$\begin{array}{l}13,16,18,20 \\
28,37,55 \\
15,16,18,19 \\
20,23\end{array}$} & $<0.01 *$ \\
\hline $\mathrm{E}$ & & $\begin{array}{l}\text { Transfused, } \\
100 \mathrm{ml} \text { blood } \\
\text { peroperatiwely }\end{array}$ & 6 & 18.8 & & $\begin{array}{l}\text { n.s.*** } \\
\text { n.s. }\end{array}$ \\
\hline
\end{tabular}

Note. All dogs received postoperative immunosuppression.

* Wilcoxon rank-sum test used for comparing the survival of the experimental group and the control group (group A).

* Wilcoxon rank-sum test used for comparing the survival of the experimental group and donor-pretreated, recipient-non transfused group (group D).

*** Wilcoxon rank-sum test used for comparing the survival of the experimental group and the nonpretreated, recipient-transfused group (group B, Table 1). 
Table 2. Kidney graft survival of pretreated and nonpretreated kidneys in mongrel dogs, which received a transfusion of third party spleen cells on Day -14 .

\begin{tabular}{|c|c|c|c|c|c|c|}
\hline Group & $\begin{array}{l}\text { Drug } \\
\text { pretreatment } \\
\text { (donor) }\end{array}$ & $\begin{array}{l}\text { Peroperative } \\
\text { blood } \\
\text { transfusion } \\
\text { (recipient) }\end{array}$ & No. & MST & Survival (days) & $P$ \\
\hline $\mathrm{A}$ & Nonpretreated & $\begin{array}{l}\text { Transfused } \\
\text { spleen cells on } \\
\text { Day -14 }\end{array}$ & 7 & 10.3 & $\begin{array}{l}5,8,8,11,12 \\
13,15\end{array}$ & n.s. * \\
\hline B & Pretreated & $\begin{array}{l}\text { Transfused } \\
\text { spleen cells on } \\
\text { Day }-1.4\end{array}$ & 7 & 12.3 & $\begin{array}{l}8,10,10,11, \\
13,16,18\end{array}$ & $<0.02 *$ \\
\hline
\end{tabular}

Note. All dogs received postoperative immunosuppression.

* Wilcoxon rank-sum test used for comparing the survival of the experimental group and the control group (group A, Table 1).

* Wilcoxon rank-sum test used for comparing the survival of the experimental group and donor-pretreated, recipient-nontransfused group (group D, Table 1).

depend on whether or not the recipient had been transfused. In nontransfused animals donor drug pretreatment with procarbazine hydrochloride and methylprednisolone induced significantly prolonged graft survival (MST 26.8 days, group D, table 1 ). In peroperatively transfused recipients, however, graft survival of pretreated kidneys was 18.8 days MST, (group E, table 1). This survival does not differ significantly from the survival after donor drug pretreatment or blood transfusion alone. The effect of donor drug pretreatment was completely abrogated when donor pretreatment was combined with a transfusion of cells from a third-party spleen on day -14 (MST 12.3 days, group B, table 2).

\section{Discussion}

The beneficial effect of preoperative blood transfusions on kidney graft survival is now generally accepted; the effectiveness of a peroperative blood transfusion is not yet well established. One peroperative blood transfusion has the advantage over multiple blood transfusions in that it prevents sensitization of the recipient. Suggestive evidence for prolonged kidney graft survival due to a peroperative blood transfusion has been obtained in man (13). We obtained a significant increase in graft survival time after a simple peroperative third-party blood transfusion in postoperatively immunosuppressed dogs. It should be noted that mild postoperative immunosuppression might be essential for enhanced graft survival induced by blood transfusions (11). A peroperative transfusion led to better results compared to one 
transfusion given 14 days before transplantation. This is in accordance with data obtained in the monkey (5).

Significant prolonged kidney graft survival in dogs could be obtained with procarbazine hydrochloride and methylprednisolone administered to the donor prior to procuring the kidney graft. The combination of donor drug pretreatment and peroperative blood transfusion did not improve graft survival compared to either treatment. A third-party spleen cell transfusion 14 days before transplantation abrogated the effect of donor pretreatment completely. The observation that donor drug pretreatment does not lead to increased graft survival in transfused recipients could explain the conflicting data on donor pretreatment in man, since in the clinical situation pretreated grafts will often be implanted in already-transfused patients. It is to be expected that transplantation centers which deliberately transfuse their potential transplantation candidates will therefore find no effect of donor pretreatment. It is of interest that until now little attention has been paid on whether or not the recipient of a drug-pretreated kidney has been transfused. Considering the findings of this study it seems worthwhile to evaluate clinical data obtained by donor pretreatment for this aspect.

\section{References}

1. Abouna G.M., Barabas A.Z., Pazderka V., Boyd N., Vetters J.M., Kinniburg D.A., Lao V.S., Schlaut J., Kavithavongs I. and Dossetor J.B. Effect of pretreatment with multiple blood transfusions and with skin grafts on the survival of renal allografts in mongrel dogs. Transplant. Proc. 9: 265, 1977.

2. Barry J.M. and Bennett W.M. Primary cadaver kidney transplant survival after donor pretreatment with cyclophosphamide and methylprednisolone. Transplantation 26: 202, 1978.

3. Bull R.W., Vriesendorp H.M., Obertop H. and Westbroek D.L. Effect of prior third party blood transfusions on canine renal allograft survival. Transplantation $26: 249,1978$.

4. Chatterjee S.N., Terasaki P.I., Fine S., Schulman B., Smith R. and Fine R.N. Pretreatment of cadaver donors with methylprednisolone in human renal allografts. Surg. Gynecol. Obstet. 145: 729, 1977.

5. Van Es A.A., Marquet R.L., Van Rood J.J., Kalff M.W. and Balner H. Blood transfusions induce prolonged kidney allograft survival in rhesus monkeys. Lancet 1: 506, 1977 .

6. Fabre J.W., Bishop M., Sen T., McKenzie J., Williams K.A., Denton T.G., Millar P.R., and Morris P.J. A study of three protocols of blood transfusion before renal transplantation in the dog. Transplantation 26: 94, 1978.

7. Guttmann R.D., Lindquist R.R., Klassen J., Knaack J., Jeffery J., Chassot P.G., and Abbou C.C. Renal transplantation in the inbred rat. XI Reduction of allograft immunogenicity by cytotoxic drug pretreatmént of donors. Transplantation 8: 490, 1969.

8. Guttmann R.D., Beaudoin J.G., Morehous D.D., Klassen J., Knaack J., 
Jeffery J., Chassot P.G. and Abbou C.C. Donor Pretreatment as an adjunct to cadaver renal allotransplantation. Transplant. Proc. 7: 117, 1975.

9. Jeffery J.R., Downs A., Grahame J.W., Lye C., Ramsey E. and Thomson A.E. A randomised prospective study of cadaver donor pretreatment in renal transplantation. Transplantation 25: 287, 1978.

10. Van der Linden C.J., Buurman W.A., Vegt P.A., Greep J.M. and Jeekel J. Prolongation of canine renal allograft survival. A study on the effect of donor pretreatment. Transplantation 30:132, 1980.

11. Obertop H., Bijnen A.B., Vriesendorp H.M. and Westbroek D.L. Prolongation of renal allograft survival in DLA tissue-typed beagles after third-party blood transfusions and immunosuppressive treatment. Transplantation 26: 255,1978 .

12. Opelz G., Sengar D.P.S., Mickey M.R., and Terasaki P.I. Effect of blood transfusion on subsequent kidney transplants. Transplant. Proc. 5: 253, 1973.

13. Stiller C.R., Sinclair N.R., Sheppard R.R., Lookwood B.L., Lillian R.A., Sharpe J.A. and Hayman P. Beneficial effect of operation-day blood transfusions on human renal-allograft survival. Lancet 1:169,1978.

14. Zincke H. and Woads J.E. Attempted immunological alteration of canine renal allograft donors. Transplantation 18: 480, 1974.

15. Zincke H. and Woods J.E. Donor pretreatment in cadaver renal transplantation. Surg. Gynecol. Obstet. 145: 183, 1977. 


\section{Acknowledgements}

The experiments described in this thesis were performed in the department of surgery, State University of Limburg, under the kindly supervision of Prof. Dr. J. Jeekel. He solved many of the experienced problems.

Prof. Dr. J.M. Greep created ample possibilities for research within his department. His inspiring leadership has made this investigation possible.

The theoretical knowhow of Dr. W.A. Buurman has been widely employed in all experiments. Extensive discussions with him improved the quality of this manuscript significantly.

P.A. Vegt has been a nice colleaque; he transplanted conscientiously a considerable amount of the kidneys.

Prof. Dr. G. Kootstra's enthousiastic support has made it possible to finish this thesis.

The technical assistance of Miss A.J.J.M. Daemen and Mrs. G.M.A.A. Jeunhomme is greatly appreciated. They were always willing to help.

I feel much obliged to Miss Marijke van den Berg for typing, retyping and re-retyping the manuscript.

Miss M. Duyzings retyped the earlier published papers.

Lastly I want to thank (Anne) Mieke for their moral support during the last four years. 


\section{Curriculum vitae}

Cees van der Linden was born on the 22nd of October, 1951 in 's-Gravenhage, The Netherlands. After graduating from high school (HBS-B), he studied at the Medical Faculty of Rotterdam from 1970 to 1976. This period was interrupted for 6 months for an experimental study concerning the immunological conditioning of incompatible bone marrow transplantations in 1973 (TNO, Rijswijk, director/Prof. Dr. D.W. van Bekkum). In 1977 the ECFMG-examination was passed. Since 1977 he is a resident in surgery in Hospital St. Annadal. Maastricht (chairman/Prof. Dr. J.M. Greep). 